\title{
Oligocene cetaceans from Baja California Sur, Mexico
}

\author{
Atzcalli Ehécatl Hernández Gisneros, Gerardo González Barba, Robert Ewan Fordyce
}

\begin{abstract}
Atzcalli Ehecatl Hernández Gisneros
atznemesis@hotmail.com

Museo de Historia Natural de la Universidad Autónoma de Baja California Sur, Universidad Autónoma de Baja California Sur, Carretera al Sur Km 5.5, Apartado Postal 19-B, C.P. 23080, La Paz, Baja California Sur, México.

Instituto Politécnico Nacional, Centro Interdisciplinario de Ciencias Marinas (CICMAR), Av. Instituto Politécnico Nacional s/n, Col. Playa Palo de Santa Rita, Apartado Postal 592, 23096, La Paz, Baja California Sur, Mexico.
\end{abstract}

\section{Gerardo González Barba}

Museo de Historia Natural de la Universidad Autónoma de Baja California Sur, Universidad Autónoma de Baja California Sur, Carretera al Sur Km 5.5, Apartado Postal 19-B, C.P. 23080, La Paz, Baja California Sur, México.

\section{Robert Ewan Fordyce}

Department of Geology, University of Otago, PO Box 56, Dunedin 9054, New Zealand.

BOL. SOC. GEOL. MEX. 2017

VOL. 69 NO. 1

P. $149-173$

\section{ABSTRACT}

Baja California Sur has an important Cenozoic marine fossil record which includes diverse but poorly known Oligocene cetaceans from Mexico. Here we review the cetacean fossil record including new observations from materials that elucidate the evolution of the Neoceti in the Pacific basin. Fossils were collected from outcrops of the El Cien Formation (Oligocene-Early Miocene) and from San Gregorio Formation (Late Oligocene). The specimens belong to the paleontological collection of Museo de Historia Natural de la Universidad Autónoma de Baja California Sur. An estimated 26 unnamed species include toothed cetaceans: possible "archaeocetes" (?Kekenodontidae); archaic Odontoceti; and the basal group Aetiocetidae, toothed mysticetes (Mysticeti). Toothless mysticetes (Chaeomysticeti) include the basal group Eomysticetidae, and balaenopterids-like forms. The Oligocene cetaceans from Baja California Sur, Mexico are diverse and represent the most southern such assemblages known from North America.

Keywords: Mysticeti, Odontoceti, Mexico, fossils, Late Oligocene

\section{RESUMEN}

Baja California Sur tiene un importante registro de fósiles marinos del Cenozoico que incluye los restos poco conocidos de cetáceos del Oligoceno de México. En este estudio ofrecemos más detalles sobre estos fósiles de cetáceos, incluyendo nuevas observaciones sobre materiales que proponen esclarecer aspectos de la evolución del grupo Neoceti dentro de la cuenca del Pacífico. Los fósiles han sido colectados de los afloramientos de la Formación El Cien (Oligoceno-Mioceno Temprano) y la Formación San Gregorio (Oligoceno Tardío). Los especímenes pertenecen a la colección paleontológica del Museo de Historia Natural de la Universidad Autónoma de Baja California Sur. Se estiman alrededor de 26 especies sin nominar que incluyen cetáceos dentados: posibles "arqueocetos" (?Kekenodontidae), odontocetos arcaicos (Odontoceti), y el grupo basal de ballenas dentadas Aetiocetidae (Mysticeti). Los misticetos barbados (Chaeomysticeti) incluyen al grupo basal Eomysticetidae y formas similares a balenopteridos. Los cetáceos del Oligoceno de Baja California Sur, México son taxonómicamente diversos y representan como tal el registro más austral conocido de Norteamérica.

Palabras clave: Mysticeti, Odontoceti, México, fósiles, Oligoceno Tardío 


\section{Introduction}

Fossil marine mammals, especially whales and dolphins (Cetacea), have been reported widely from around the Pacific margin. Many species have been named from localities in western North America from Alaska to California, Peru, New Zealand, eastern Australia, and Japan. In Mexico Oligocene marine mammals from Baja California Sur have been reported since the 1940s, and most of the identified Oligocene fossils are cetacean, but desmostylids are known and some fragmentary bones could belong to sirenians and pinnipeds. These occurrences are important in providing insights into the poorly understood marine mammals of Oligocene age from warm temperate to subtropical settings.

Amongst the early records, Vanderhoof (1942) and Durham (1950) reported remains of the desmostylian Cornwallius sookensis (Cornwall, 1922), and other fossil bones from Punta San Telmo (Tembabichi Member, locality "miembro Punta San Carlos" in Bahía San Carlos). Other marine mammal fossils were reported in the 1970s, from Punta San Telmo, San Hilario, El Cien, and San Juan de la Costa (Applegate and Wilson, 1976). One skull of a baleen whale from the El Cien locality was considered similar to the Oligocene-Miocene mysticete Mauicetus parki (Benham, 1937) from New Zealand (Downs and Morris, 1974).

Reports from the 1980s include fragments of odontocete mandibles from the Aguajito area and squalodontid teeth are known from the phosphatic sandstones at the locality "Diez minutos" (near El Cien village). Mysticete skulls are known from localities north of La Fortuna and in the vicinity of Tembabichi (Applegate, 1986). The whereabouts of specimens collected or reported during the 1940 s to early 1990 s are unknown but some may be in the Universidad Autónoma de México (UNAM) collections (see Barnes, 1998).

Around 16 species of cetaceans were reported during the 1990s from outcrops of San Juan Member, El Cien Formation (in the village of San
Juan de la Costa, El Cien and San Hilario), based on field observations and uncatalogued specimens from the collections of the Museo de Historia $\mathrm{Na}$ tural de la Universidad Autónoma de Baja California Sur (MHN-UABCS) and material from the Museo Regional de Antropología e Historia de Baja California Sur (Barnes, 1998). Other unpublished specimens from the San Juan Member include a skull of a putative agorophiid odontocete (Cruz-Marín, 1997) and a skull of an archaic toothed mysticete (Olivares-Bañuelos, 2001).

The Oligocene cetacean fossil record from Baja California Sur is restricted to the San Gregorio Formation and El Cien Formation (Figure 1). Most of the specimens are from the San Juan Member (El Cien Formation), from localities near the village of San Juan de la Costa. However, it is known that the distribution of fossils is broader, with abundant material in places like El Aguajito, El Cien, Cerro Colorado, Tembabichi (Tembabichi Member, El Cien Formation) and La Purísima (San Gregorio Formation).

Since the 2000s more cetacean fossils have been collected from the Oligocene outcrops in Baja California Sur, leading to recent published mentions and some provisional identification (González-Barba, 2007; Hernández-Cisneros and González-Barba, 2013). In summary, the fossil record is diverse at species to family level, but identifications are provisional because most of the specimens need detailed preparation, and the specimens are largely unpublished. Nevertheless, the Oligocene cetaceans from Baja California Sur are potentially important to understand the initial evolutionary radiation of the Neoceti - the two extant clades of Mysticeti (filter-feeding baleen whales) and Odontoceti (echolocating dolphins and toothed whales). The aim here is to review Oligocene cetacean assemblages from Baja California Sur, and add details of specimens that have previously been mentioned only in unpublished theses or abstracts. The geographic distribution and stratigraphy of the main source horizons are summarized. Fossils of Oligocene cetaceans recently cataloged in MHN-UABCS collections improve knowledge of 
Oligocene cetacean diversity in Baja California Sur (Hernández-Cisneros, 2012).

\section{Study area and geological setting}

Fossiliferous Oligocene rocks in Baja California Sur include: the San Gregorio Formation, locat- ed around La Purísima $250 \mathrm{~km}$ north of La Paz near the Pacific coast (Fischer et al., 1995); the Tembabichi Member, El Cien Formation, on the coast of the Gulf of California, approximately 50 $\mathrm{km}$ north of the Bahía de La Paz (Fischer et al., 1995; Plata-Hernández, 2002); and the San Juan Member, El Cien Formation, which lies between the bay in the East and the State Road 1 in the

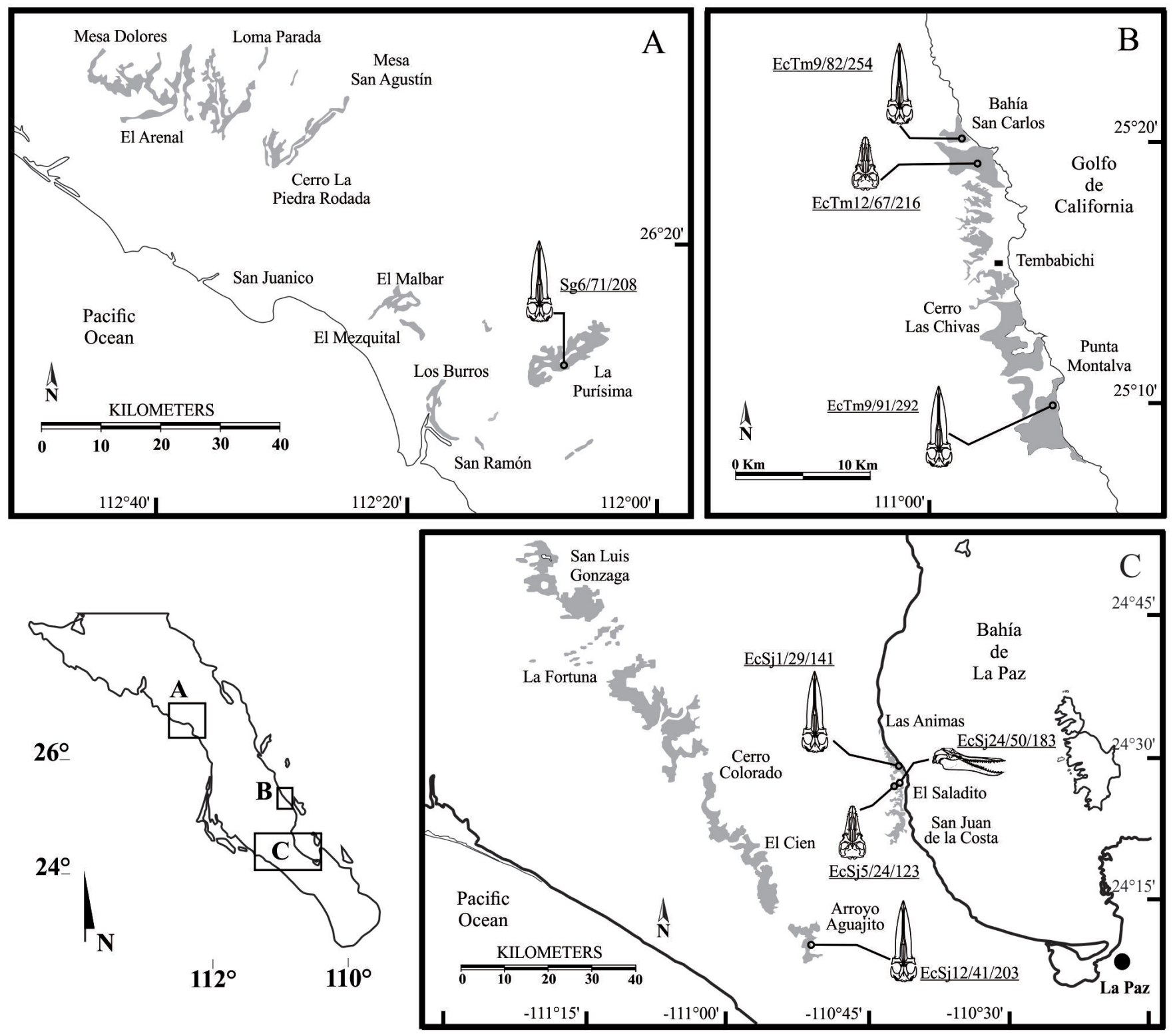

Figure 1 Geologic map of Oligocene outcrops in Baja California Sur, and some representative specimens collected from the localities. San Gregorio Formation (A), Tembabichi Member of the El Cien Formation, (B), and San Juan Member of the El Cien Formation (C), Geological distribution extracted from the map of the Servicio Geológico Mexicano (Alexadri-Rionda et al., 2008). 
west (Fischer et al., 1995) 40 km north of La Paz (Figure 1).

The localities of the San Gregorio Formation are small outcrops along the banks and stream bottoms of the largest arroyos (McLean et al., 1987), unlike the more extensive distribution of the Tembabichi and San Juan members. Oligocene outcrops are discontinuous and reflect different depositional environments with relatively similar stratigraphy that include phosphatic sandstone beds, mudstone, diatomite, coquina and conglomerates (Hausback, 1984; Fischer et al., 1995).

The San Gregorio Formation is characterized by dark finely to very finely laminated biosiliceous sediments -white diatomite, diatomaceous clay, porcelanite, silty porcelanite and chert (Grimm and Föllmi, 1994), with several alternating sequences of phosphatic layers, siliceous siltstone, phosphatic mudstone with fish scales, and rhyolitic tuffs (McLean et al., 1987). The Tembabichi Member consists of siltstones, sandstones, mudstones, coquina, phosphatic horizons, and dolomitic beds and it is considered correlative to the San Juan Member as a lateral variation of the same basin deposit (Plata-Hernandez and Schwennicke, 2000; Plata-Hernandez, 2002). The San Juan Member is mainly composed of laminated, partly tuffaceous, siliceous, diatomaceous or phosphatic mudstones, partly phosphatic silt- and sandstones, granular phosphorite, tuff, and conglomerates (Fischer et al., 1995).

The depositional environment for the San Gregorio Formation is interpreted as deposits from water depths between 500 and 2500 m based on planktic foraminifers and trace fossils (McLean et al., 1987; Grimm and Föllmi, 1994). In contrast, sediments of El Cien Formation were deposited no deeper than $200 \mathrm{~m}$, suggesting shelf environments, coastal lagoons, estuaries and deltas (Schwennicke, 1994). Past studies of diatoms (Kim and Barron, 1986), planktonic foraminifera (Kim, 1987), and calcareous nannofossils (McLean et al., 1987; Schwennicke, 1992), shark and ray faunas (González-Barba, 2008), macroinvertebrates -e.g. mollusks and crabs (Smith, 1991; Grimm and
Föllmi, 1994; Schweitzer et al., 2002; Vera-Dimas, 2013), phosphorites (Galli-Olivier et al., 1990; Galli-Olivier, 1993; Schwennicke, 1994; Schwennicke and Vázquez-García, 1996), and sedimentological studies (Grimm, 1992) have elucidated the paleobiological and paleoceanographic history of the region during the Late Oligocene and indicate a subtropical environment characterized by high primary productivity.

The age for the Oligocene sequences range $\sim 30$ to $23 \mathrm{Ma}$. The thickness for the main exposed section of San Gregorio Formation is $\sim 75 \mathrm{~m}$ (Ganz, 1996), and has been dated as $\sim 27$ to $22 \mathrm{Ma}$ (Late Oligocene-Early Miocene) based on K/Ar, calcareous nannofossils (Discoaster) and diatoms -Rocella gelida (Bukry, 1978) (Kim and Barron, 1986; McLean et al., 1987). For the Tembabichi Member, the type section is $\sim 135 \mathrm{~m}$ thick (Grimm, 1992), with an age of $\sim 28$ to 25.9 Ma dated with K/Ar and $\mathrm{Rb} / \mathrm{Sr}$ using tuff beds (Hausback, 1984; Plata-Hernández, 2002). Thickness of the San Juan Member varies from $75 \mathrm{~m}$ at Aguajito locality to $130 \mathrm{~m}$ at San Juan de la Costa locality (Schwennicke and Vázquez-García, 1996). Its age is $~ 30$ to $23 \mathrm{Ma}$ based on $\mathrm{K} / \mathrm{Ar}$ dates for biotite from a tuff bed (Hausback, 1984), diatom biostratigraphy -Rocella vigilans Fenner, 1982, Bogorovia veniamini, Jousé, 1973, R. gelia (Kim and Barron, 1986), foraminifera representing zones P21 and P22 (Kim, 1987) and calcareous nannofossils representing the NP24/NP25 zones (Schwennicke, 1992).

\section{Methods and Materials}

This study involved field exploration, preparation, identification, and catalog of Oligocene cetacean fossils from MHN-UABCS collection. We reviewed the available literature, outcrops and fossils of the San Gregorio and El Cien formations. Field collections of fossil material for MHN-UABCS began in 1988, and were recorded by Gerardo González Barba, from 1991 to present. New observations (Table 1) are derived from Hernández-Cisneros (2012, 2014, 2015), Fordyce et al., 
(2012), Hernández-Cisneros and González-Barba (2013), and Hernández-Cisneros et al., (2014). References for taxa mostly cite the original author, using the author-comma-date convention (with parentheses as appropriate) of the International Code of Zoological Nomenclature.

Institutional abbreviations. MHN-UABCS (MU), Museo de Historia Natural de la Universidad Autónoma de Baja California Sur, La Paz, Baja California Sur, Mexico; OU, specimen curated in Geology Museum, University of Otago, Dunedin, New Zealand; USNM, specimen curated in the National Museum of Natural History, Smithsonian Institution, Washington D.C.

\section{Results}

Cetacean fossils are sporadic to common in Late Oligocene outcrops of El Cien Formation and San Gregorio Formation. Generally the fossils occur within phosphatic sandstone near the top of the sequence (Appendix Figure A1). In contrast, the Tembabichi area has abundant fossils which are associated with siltstones and phosphatic sandstones, and appear in the section close to the top, in the middle part (mostly allochthonous in phosphatic beds), and close to the base -above $\sim 30-35 \mathrm{~m}$ in the stratigraphic column (Appendix Figure A2). The fossils are in concretions or are scattered fragments on the surface. In the San Juan Member, the fossil distribution is similar to Tembabichi Member. The top of the San Juan Member is capped by a conglomerate with sporadic marine mammal fossils in some localities to the north of El Saladito. In the middle part of the exposed stratigraphic section in San Juan de la Costa complete skeletons occur mainly in the zones where the phosphorite mine work is active. More cetacean bones can be found close to the base of the San Juan Member, $\sim 20 \mathrm{~m}$ above the lower limit at Aguajito locality (Appendix Figure A3).

Fossil cetaceans from Baja California Sur are noteworthy in terms of number of species and individuals, which represent two major taxonomic groups: the paraphyletic Archaeoceti or stem-Cetacea, and the monophyletic Neoceti (Mysticeti and Odontoceti) or crown-Cetacea. Specimens generally show enough distinctive features to be separated at species level, thus allowing minimum counts for species, but few are preserved or prepared well enough to justify naming at this stage of research.

Some Mysticeti specimens, as MHN-UABCS_ EcSj5/24/123 (Figure 2A) exhibit synapomorphies of the family Aetiocetidae, including a premaxilla that overhangs the maxilla adjacent to the bony naris (Fitzgerald, 2010) and a short overlap of the jugal and the zygomatic process of the squamosal (Deméré and Berta, 2008) - from here MU will be used for MHN-UABCS in the series-collection to give an easy read (see the complete specimen references in Table 1).

Well preserved toothless mysticetes (Figure 2C, 3) share similar cranial features with eomysticetids like Eomysticetus and Micromysticetus (Sanders and Barnes, 2002a, 2002b), Yamatocetus (Okazaki, 1995, 2012) and Tohoraata, Waharoa and Tokarahia (Boessenecker and Fordyce, 2014, 2015a, 2015b). In general these specimens have a long, narrow skull, including an elongate and narrow intertemporal region, elongate nasals, a large temporal fossa, an elongate zygomatic process of the squamosal that extends beyond the apex of the supraoccipital, and a long-based and high coronoid process. The family identities of other fossil mysticetes are unclear.

Few Oligocene Odontoceti skulls have been identified, but it is likely that the number of specimens will increase with more field work, given the success of recent prospecting. Fordyce et al. (2012) presented preliminary details of a new group of archaic odontocetes that are structurally similar to New Zealand Oligocene "dalpiazinid" dolphins, but more derived in some cranial features. These specimens, which are undescribed, include MU EcSj24/50/183 (Figure 5B). The latter Baja California Sur specimen is phylogenetically close to USNM205491 from the Alsea Formation of Oregon, $\leq 30$ Ma (Snavely et al., 1975). 

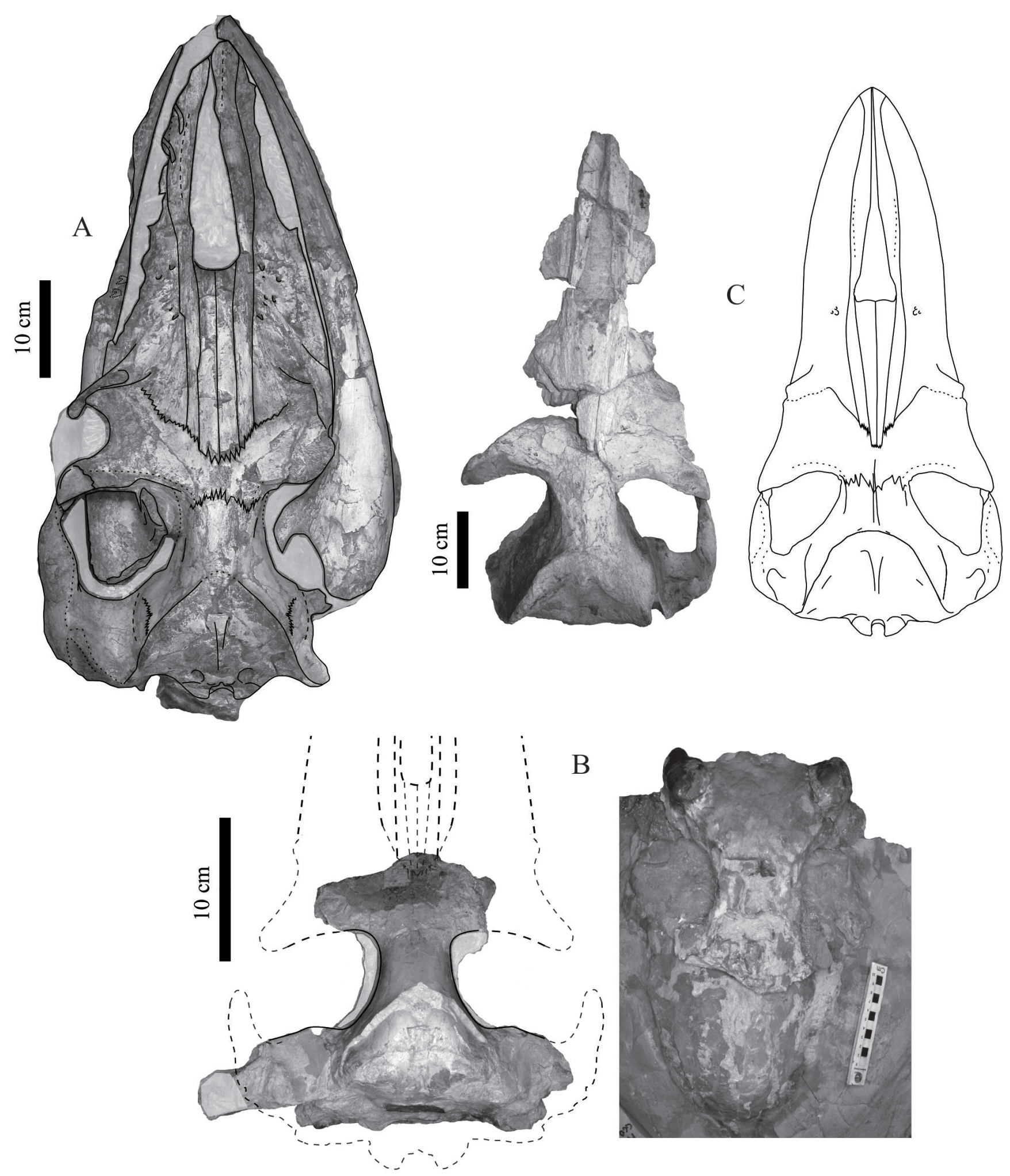

Figure 2 Late Oligocene cetacean fossils from Baja California Sur, México. (A) Dorsal view, skull of an unnamed aetiocetid, MU EcSj5/24/123. (B) Left, dorsal view, partial skull, MU EcSj9/08/36, ?Chonecetus sp., and right, concretion with the partial skull in ventral view. Continuous lines show anatomical details, and dashed lines mark missing anatomy. Shaded white areas show sediment matrix. (C) Dorsal view, juvenile skull of an unnamed eomysticetid, MU EcSj1/29/141, and reconstruction scheme, right. 
Table 1. Representatives list of Late Oligocene cetaceans from Baja California Sur.

\begin{tabular}{|c|c|c|c|c|c|c|}
\hline Taxon & Specimen & Material & Age & Locality & Formation & Member \\
\hline \multicolumn{7}{|l|}{ 'Archaeoceti' } \\
\hline \multicolumn{7}{|l|}{ ?Kekenodontidae } \\
\hline \multirow{6}{*}{ Gen. et spp. indet. } & MHN-UABCS_EcSj1/45/214 & Partial skull with periotics. & Late Oligocene & Mesa El Tesoro, San Juan de la Costa. & El Cien & San Juan \\
\hline & MHN-UABCS_EcSj1/94/296 & Partial skull. & Late Oligocene & Mesa El Tesoro, San Juan de la Costa. & El Cien & San Juan \\
\hline & MHN-UABCS_EcSj5/16/72 & Left frontal fragment (Fig. 6B). & Late Oligocene & $\begin{array}{l}\text { Terreros El Saladito, San Juan de la } \\
\text { Costa. }\end{array}$ & El Cien & San Juan \\
\hline & MHN-UABCS_EcSj1/38/155 & Partial skull. & Late Oligocene & Mesa El Tesoro, San Juan de la Costa. & El Cien & San Juan \\
\hline & MHN-UABCS_EcSj24/59/206 & Two premolars teeth. & Late Oligocene & $\begin{array}{l}\text { San Juan de la Costa, "Arroyo } \\
\text { Tarabillas" }\end{array}$ & El Cien & San Juan \\
\hline & MHN-UABCS_EcTm12//67/216 & Partial skull and tympanic bullae. & Late Oligocene & Cañada La Montosa, San Carlos & El Cien & Tembabichi \\
\hline \multicolumn{7}{|l|}{ Mysticeti } \\
\hline \multicolumn{7}{|l|}{ Aetiocetidae } \\
\hline Aetiocetus sp. indet. & MHN-UABCS_EcSj5/24/123 & $\begin{array}{l}\text { Skull, left tympanic bulla, teeth, dentary, } \\
\text { cervical vertebrae (Fig. } 2 \text { A). }\end{array}$ & Late Oligocene & $\begin{array}{l}\text { Terreros El Saladito, San Juan de la } \\
\text { Costa. }\end{array}$ & El Cien & San Juan \\
\hline \multicolumn{7}{|l|}{ Chaeomysticeti } \\
\hline \multicolumn{7}{|l|}{ ?Balaenopteroidea } \\
\hline Fam. indet. Gen. et sp. indet. & MHN-UABCS_EcSj12/41/203 & $\begin{array}{l}\text { Partial skull and tympanic bullae, left } \\
\text { mandible, vertebrae. }\end{array}$ & Late Oligocene & $\begin{array}{l}\text { Aguajito de Castro, Carretera Norte N. } \\
1\end{array}$ & El Cien & San Juan \\
\hline Fam. indet. Gen. et sp. indet. & MHN-UABCS_EcSj1/29/143 & Braincase. & Late Oligocene & Mesa El Tesoro, San Juan de la Costa. & El Cien & San Juan \\
\hline \multicolumn{7}{|l|}{ Eomysticetidae } \\
\hline \multirow{2}{*}{ Gen. et spp. indet. } & MHN-UABCS_EcTm $9 / 82 / 254$ & Braincase. & \multirow{2}{*}{ Late Oligocene } & \multirow{2}{*}{$\begin{array}{l}\text { Miembro Punta San Carlos, San } \\
\text { Carlos. Mesa El Tesoro, San Juan de } \\
\text { la Costa. }\end{array}$} & \multirow{2}{*}{ El Cien } & Tembabichi \\
\hline & MHN-UABCS_EcSj1/29/276 & Braincase and fragments. & & & & San Juan \\
\hline Gen. et sp. indet. & MHN-UABCS_Sg6/71/208 & Skull, tympanic bullae, dentary. & Late Oligocene & Rio La Purísima, La Purísima. & San Gregorio & -- \\
\hline Gen. et $s p$. indet. & MHN-UABCS_EcSj1/29/142 & $\begin{array}{l}\text { Partial skull, } 15 \text { vertebrae (including } \\
\text { cervical), fragmentary bones (Fig. 3). }\end{array}$ & Late Oligocene & Mesa El Tesoro, San Juan de la Costa. & El Cien & San Juan \\
\hline Gen. et sp. indet. & MHN-UABCS_EcSj1/29/141 & $\begin{array}{l}\text { Partial skull, four thoracic vertebrae, } \\
\text { one caudal vertebra, ear bone fragments, } \\
\text { and bones (Fig. 2C). }\end{array}$ & Late Oligocene & Mesa El Tesoro, San Juan de la Costa. & El Cien & San Juan \\
\hline \multicolumn{7}{|l|}{ Unknown Chaeomysticeti } \\
\hline Fam. indet. Gen. et sp. indet. & MHN-UABCS_EcSj1/47/168 & Partial skull. & Late Oligocene & Mesa El Tesoro, San Juan de la Costa. & El Cien & San Juan \\
\hline Fam. indet. Gen. et sp. indet. & MHN-UABCS_EcTm9/82/257 & Partial skull. & Late Oligocene & $\begin{array}{l}\text { Miembro Punta San Carlos, San } \\
\text { Carlos. }\end{array}$ & El Cien & Tembabichi \\
\hline \multirow{2}{*}{ Fam. indet. Gen. et spp. indet. } & MHN-UABCS_EcSj5/06/31 & Partial skull, left periotic (Fig. 4A). & Late Oligocene & $\begin{array}{l}\text { Terreros El Saladito, San Juan de la } \\
\text { Costa. }\end{array}$ & El Cien & San Juan \\
\hline & MHN-UABCS_EcSj5/18/95 & $\begin{array}{l}\text { Partial skull, left bulla and periotic (Fig. } \\
\text { 4B). }\end{array}$ & Late Oligocene & $\begin{array}{l}\text { Terreros El Saladito, San Juan de la } \\
\text { Costa. }\end{array}$ & El Cien & San Juan \\
\hline Fam. indet. Gen. et sp. indet. & MHN-UABCS_EcSj1/29/145 & Partial skull. & Late Oligocene & Mesa El Tesoro, San Juan de la Costa. & El Cien & San Juan \\
\hline Fam. indet, Gen. et sp. indet. & MHN-UABCS_EcSj1/51/184 & Partial skull with right tympanic bullae. & Late Oligocene & Mesa El Tesoro, San Juan de la Costa. & El Cien & San Juan \\
\hline Fam. indet. Gen. et sp. indet. & MHN-UABCS_EcTm9/91/292 & Partial skull. & Late Oligocene & Cañada El Mangle. Punta Montalva. & El Cien & Tembabichi \\
\hline \multicolumn{7}{|l|}{ Odontoceti } \\
\hline \multicolumn{7}{|l|}{ ?Squalodontidae } \\
\hline Gen. et sp. indet. & MHN-UABCS_EcSj25/39/157 & Articulated mandible with teeth. & Late Oligocene & $\begin{array}{l}\text { Cañada de la Luz, San Juan de la } \\
\text { Costa. }\end{array}$ & El Cien & San Juan \\
\hline \multicolumn{7}{|l|}{ ?Dalpiazinidae } \\
\hline Gen. et $s p$. indet. & MHN-UABCS_EcSj5/35/151 & Left dentary with teeth. & Late Oligocene & $\begin{array}{l}\text { Terreros El Saladito, San Juan de la } \\
\text { Costa. }\end{array}$ & El Cien & San Juan \\
\hline \multicolumn{7}{|l|}{ Unknown Odontoceti } \\
\hline \multirow[t]{2}{*}{ Fam. indet. Gen. et spp. indet. } & MHN-UABCS_EcSj5/12/48 & $\begin{array}{l}\text { Skull, right bulla, periotics, cervical } \\
\text { vertebrae; humerus, right ulna and } \\
\text { radius, rib fragments (Fig. 5A). }\end{array}$ & Late Oligocene & $\begin{array}{l}\text { Terreros El Saladito, San Juan de la } \\
\text { Costa. }\end{array}$ & El Cien & San Juan \\
\hline & *MHN-UABCS_EcSj1/50/177 & Partial skull. & Late Oligocene & Mesa El Tesoro, San Juan de la Costa. & El Cien & San Juan \\
\hline Fam. indet. Gen. et sp. indet. & ${ }^{*}$ MHN-UABCS_EcSj1/44/165 & Partial skull. & Late Oligocene & Mesa El Tesoro, San Juan de la Costa. & El Cien & San Juan \\
\hline Fam. indet. Gen. et sp. indet. & *MHN-UABCS_EcSj5/49/176 & Partial skull. & Late Oligocene & $\begin{array}{l}\text { Terreros El Saladito, San Juan de la } \\
\text { Costa. }\end{array}$ & El Cien & San Juan \\
\hline Fam. indet. Gen. et sp. indet. & ${ }^{*}$ MHN-UABCS_EcSj24/50/183 & Partial skull (Fig. 5B) & Late Oligocene & $\begin{array}{l}\text { Arroyo Tarabillas, San Juan de la } \\
\text { Costa }\end{array}$ & El Cien & San Juan \\
\hline
\end{tabular}

* Specimens in process of description with the collaboration of Robert Ewan Fordyce from the University of Otago, Dunedin, New Zealand. 
Probable kekenodontids are represented by: a periotic, MU EcSj5/16/267 (Figure 6A); a left frontal fragment, MU EcSj5/16/72 (Figure 6B); and unprepared skulls, MU EcSj1/45/214, EcSj1/94/296, and EcSj1/38/155 (Hernández-Cisneros, 2015). These specimens are similar to an undescribed specimen (OU 22294) from the Kokoamu Greensand-basal Otekaike Limestone of the Waitaki Valley region (26-28+ Ma, Late Oligocene; Fordyce, 2004) from New Zealand.

\subsection{SYSTEMATIC PALEONTOLOGY}

\subsubsection{SUBORDER MYSTICETI-AETIOCETIDAE}

Cetacea Brisson, 1762

Neoceti Fordyce \& de Muizon, 2001

Mysticeti Gray, 1864

Aetiocetidae Emlong, 1966

?Aetiocetus Emlong, 1966

\section{?Aetiocetus sp.}

Material. MHN-UABCS_EcSj5/24/123, skull (Figure 2A).

Locality. El Saladito, "Mesa El Saladito", San Juan de la Costa (24.43929 N, 110.70042 W), La Paz, Baja California Sur, México. Collected by Gerardo González Barba and Raúl Agundez Arce. March 1996.

\section{Formation. El Cien Formation.}

Age -28 to $25 \mathrm{Ma}$ approximately, Late Oligocene (Fischer et al., 1995).

Description. The specimen (Figure 2A) consists of a skull with a condylobasal length of $\sim 760 \mathrm{~mm}$, a bizygomatic width of $\sim 320 \mathrm{~mm}$ and an estimated body length of $\sim 3.03 \mathrm{~m}$ derived from the bizygomatic width (following Pyenson and Sponberg, 2011). The inferred age class is a subadult individual, as indicated by the nature of the cranial sutures which are mainly closed but not fused or obliterated. The occipital condyles, ear bones, and postcranial elements generally lack fine details. Features of note include: elongate and narrow nasal bones 5-6 \% longer than in Aetiocetus weltoni (see Barnes et al., 1995), a wide and short mesorostral groove, thick and elongate zygomatic process of squamosal without the thin dorsoventral shape in its middle portion, and a wide temporal fossa. These features contrast notably with Fucaia goedertorum (Barnes et al., 1995), A. weltoni, and Aetiocetus polydentatus both of Barnes et al., 1995, and Aetiocetus cotylalveus Emlong, 1966. The features differ in part from those of Aetiocetus tomitai Barnes et al., 1995, Morawanocetus yabukii Barnes et al., 1995, Chonecetus sookensis Russell, 1968 (see also Barnes et al., 1995), Fucaia buelli Marx et al., 2105 and Willungacetus aldingensis Pledge, 2005 (see also Fitzgerald, 2010). Other notable features include multiple dorsal infraorbital foramina, thin and elongate lacrimal with lobed end, intertemporal region without sagittal crest, a slightly convex supraoccipital shield with a semicircular-triangular outline and a weak external occipital crest on middle line. The specimen is placed in Aetiocetus because it has some synapomorphies for the group (Fitzgerald, 2010), such as an incompletely open mesorostral groove partially roofed by the premaxilla, and the anterior edge of the nasals is forward of the anterior edge of the supraorbital process of frontal.

\section{?Chonecetus Russell, 1968}

\section{?Chonecetus sp.}

Material. MHN-UABCS_EcSj9/08/36, partial skull, tympanic bullae, few teeth and jaw fragments. (Figure 2B).

Locality. Mina "Las Crucecitas", San Juan de la Costa (24.40859 N, 110.69608 W), La Paz, Baja California Sur, México. Collected by Gerardo González Barba and Ruben Castro Arvizá. August 1992.

Formation. El Cien Formation.

Age. 28 to $25 \mathrm{Ma}$ approximately, Late Oligocene (Fischer et al., 1995).

Description. The specimen (Figure 2B) consists of a partial skull with both tympanic bullae, and jaw fragments with few teeth; its preserved length is $400 \mathrm{~mm}$, without occipital condyles, bizygomatic width is estimated at $\sim 300 \mathrm{~mm}$, and the calculated body length is $\sim 2.86 \mathrm{~m}$ (following Pyenson 
and Sponberg, 2011). The age class is adult, as indicated by generally closed cranial sutures. Features of note are: a fine suture in the middle line of the frontal; a convex, soft and tenuous sagittal crest on the intertemporal region; a broad intertemporal region ( $\sim 59 \mathrm{~mm}$ wide) with a $\mathrm{U}$ upside down shape, and a total width between postorbital processes of $\sim 240 \mathrm{~mm}$. These features contrast with the type species of Chonecetus, C. sookensis Russell, 1968 and F. goedertorum (Barnes et al., 1995). Nevertheless, the specimen is placed in Chonecetus because it shows some synapomorphies that Fitzgerald (2010) recognized for that genus: dorsal braincase edge low and flat, with a profile less of $10^{\circ}$ to the lateral edge of the rostrum; possibly a $\mathrm{V}$-shape frontoparietal suture, and a low nuchal crest of the supraoccipital that apparently does not project laterally or dorsolaterally. Conversely, MU EcSj9/08/36, contrasts with the recently named Fucaia buelli (see Marx et al., 2015) in the anteroposterior extension of supraoccipital and thickness of the sagittal crest.

\subsubsection{SUBORDER MYSTICETI-EOMYSTICETIDAE}

Chaeomysticeti Mitchell, 1989

Eomysticetidae Sanders \& Barnes, 2002b

Eomysticetidae gen. et. sp. indet. 1

Material. MHN-UABCS_EcSj1/29/141, skull, four thoracic vertebrae, one caudal vertebra, ear bone fragments, and bone fragments (Figure 2C).

Locality. Mesa Tesoro, San Juan de la Costa (24.47366 N, 110.69646 W), La Paz, Baja California Sur, México. Collected by Gerardo González Barba; Lawrence G. Barnes; James L. Goedert, and two anonymous collectors (Luisa and Memo), November 1999.

Formation. El Cien Formation.

Age. 28 to $25 \mathrm{Ma}$ approximately, Late Oligocene (Fischer et al., 1995).

Description. The specimen (Figure 2C) consists of a partial skull of a juvenile mysticete, and associated elements. The age class is indicated by cranial sutures which are moderately but not fully closed, e.g. the junction of the squamosal and parietal is still quite apparent. Estimated condylobasal length is $\sim 620 \mathrm{~mm}$; bizygomatic width is $\sim 320 \mathrm{~mm}$, and body length is $\sim 3.03 \mathrm{~m}$ (following Pyenson and Sponberg, 2011). Features include: elongate, triangular, nasal bones; a wide frontal similar to Yamatocetus canaliculatus Okazaki, 2012 (see also Okazaki, 1995); a short and relatively thick intertemporal region with a fine sagittal crest, a supraoccipital shield with a semicircular outline similar to mammalodontids and archaeocetes; an external occipital crest, vertical nuchal crests; and a squamosal prominence like a fingertip on the posterolateral part of squamosal (Hernández-Cisneros et al., 2014). The specimen is placed within Eomysticetidae because it shows: rigid, firmly sutured nasals and premaxillae; posteriorly elevated nuchal crest as the highest point of the skull; anteroposteriorly oriented zygomatic process; and longitudinally twisted zygomatic process that lacks a supramastoid crest (features discussed by Boessenecker and Fordyce, 2015a, 2015b).

Eomysticetidae gen. et. sp. indet. 2

Material. MHN-UABCS_EcSj1/29/142, partial skull, four cervical vertebrae, eight thoracic vertebrae, four lumbar vertebrae, and fragmentary bones (Figure 3).

Locality. Mesa Tesoro, San Juan de la Costa $\left(24.47366^{\circ} \mathrm{N}, 110.69646^{\circ} \mathrm{W}\right)$, La Paz, Baja California Sur, México. Collected by Gerardo González Barba; Lawrence G. Barnes; James L. Goedert, and two anonymous collectors (Luisa and Memo), November 1999.

Formation. El Cien Formation.

Age. 28 to $25 \mathrm{Ma}$ approximately, Late Oligocene (Fischer et al., 1995).

Description. The specimen (Figure 3) includes of a partial skull, lacking the condyles and rostrum apex, with a preserved total length of 1100 $\mathrm{mm}$. Assuming proportions similar to those in $\mathrm{E}^{-}$mysticetus whitmorei Sanders and Barnes, 2002 the complete condylobasal length could have reached $\sim 1600 \mathrm{~mm}$. The vertebrae are unprepared. The age class is subadult as indicated by cranial su- 

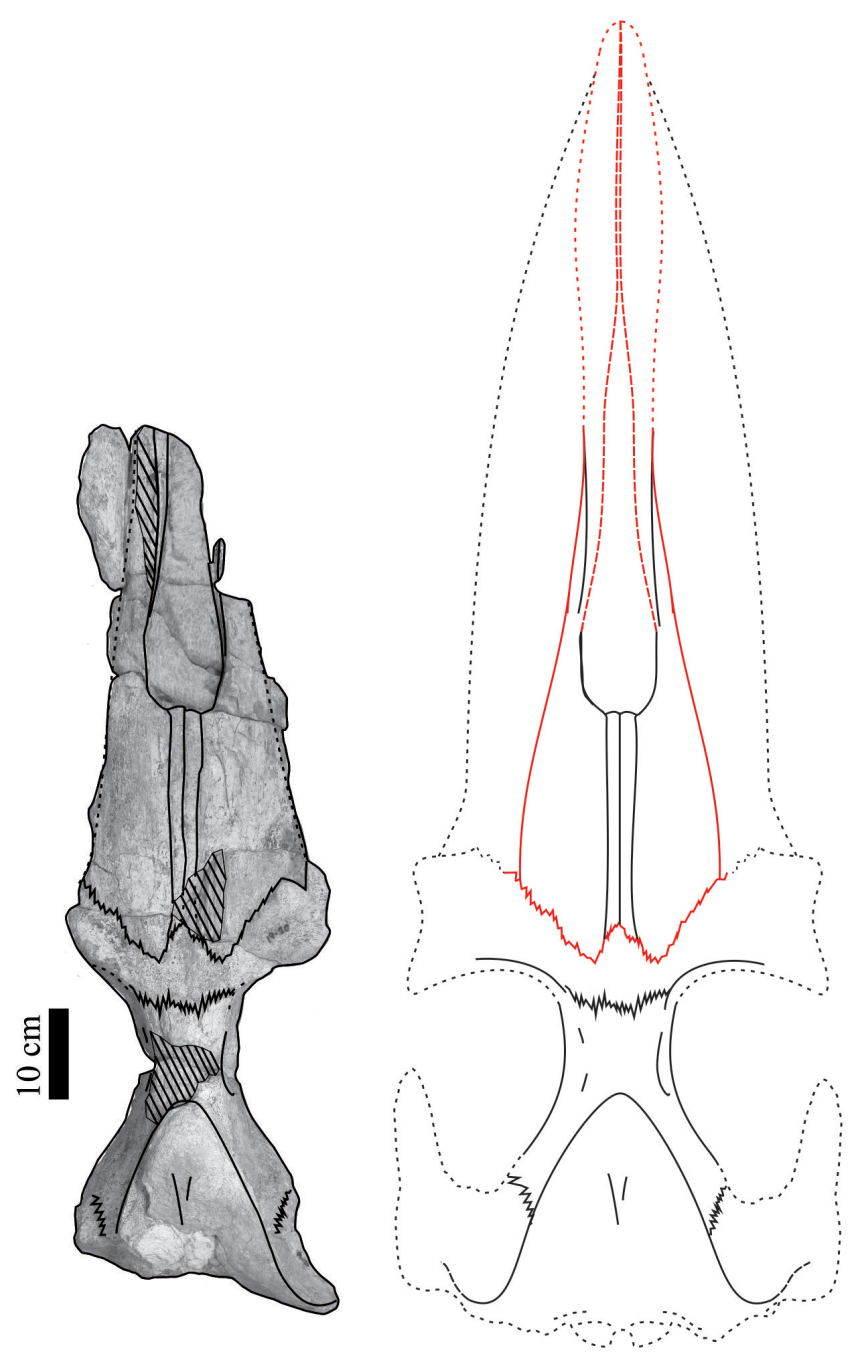

Figure 3 Dorsal view, skull of an unnamed eomysticetid, MU EcSj 1/29/142; reconstruction scheme, right, red lines show the premaxillae as the distinctive feature. Continuous lines show anatomical details, dashed lines mark missing anatomy, and diagonal lines mark broken areas.

tures which are well closed, but distinct, and not completely fused. Features of note include: very narrow elongate nasal bones; a wide mesorostral groove; a narial process of the frontals; and an extended ascending process of the premaxilla which forms a broad posterior apex that covers part of the frontal. Posteriorly, behind the level of the orbit, a serrate suture runs obliquely anterolaterally toward the region of the lacrimal and/or antorbital notch. This suture forms the posterior margin of the ascending process of the maxilla with an uncertain contribution from the premaxilla. This specimen differs in the latter structure of the premaxilla from Yamatocetus, Eomysticetus, the New Zealand eomysticetids, and other known eomysticetids (Hernández-Cisneros, unpublished data). The specimen is placed in Eomysticetidae because the cranial morphology is phenetically similar to other eomysticetids in features including: a narrow and long rostrum, firmly or rigidly sutured nasals and premaxillae; supraorbital process of frontal medially elongated and transversely narrow; intertemporal region exposed (parietal + frontal); and a large temporal fossa (characters reviewed by Boessenecker and Fordyce, 2015a, 2015b).

\subsubsection{SUBORDER MYSTICETI-CHAEOMYSTICETI}

Family indet. gen. et. sp. indet.

Material. MHN-UABCS_EcSj5/06/31, partial skull with left periotic; and MHN-UABCS_ EcSj5/18/95, partial skull with a left bulla and periotic (Figure 4).

Locality. San Juan de la Costa, El Saladito, mine spoils (24.43916 N, 110.69512 W). La Paz, Baja California Sur, México. Collected by Gerardo González Barba, December 1991 and May 1994. Formation. El Cien Formation.

Age -28 to $25 \mathrm{Ma}$ approximately, Late Oligocene (Fischer et al., 1995).

Description. The specimens (Figure 4) consist of two partial skulls which differ from each other in dorsal cranial morphology, but share a similar periotic bone. The condylobasal length is lost for both, but other size estimates are possible. MU EcSj5/06/31 has an estimated bizygomatic width of $\sim 750 \mathrm{~mm}$ based on the dimension from the midline at the condyle to the margin of the $\mathrm{zy}$ gomatic process. The condyle width is $\sim 126 \mathrm{~mm}$, and its calculated size body is 6.65 to $7.70 \mathrm{~m}$ using the equations for stem Mysticeti and stem Balaenopteroidea in Pyenson and Sponberg (2011). MU EcSj5/18/95 is fragmentary, comparable in size with MU EcSj5/06/31, but with no meaningful standard dimensions preserved. Both specimens are subadults as indicated by cranial sutures that are not completely fused. Features of note include: a periotic bone with very flat (transversely 


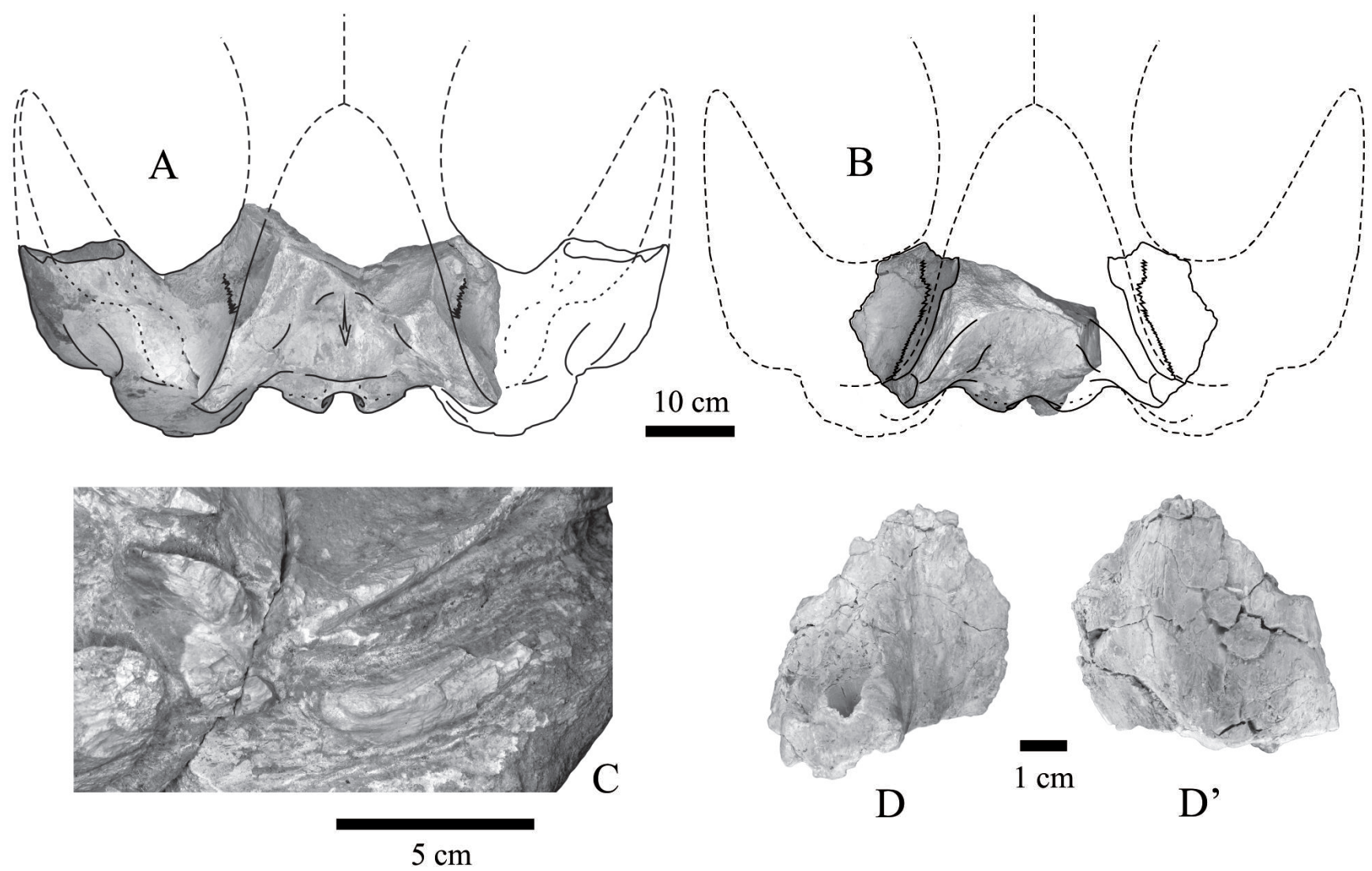

Figure 4 (A-B) Dorsal view, partial skulls, unnamed mysticetes, MU EcSj5/06/31, left; and MU EcSj5/18/95, right. (C) Left periotic bone in situ of MU EcSj5/06/31, ventral view. (D-D') broken left periotic of MU EcSj5/18/95, medial view, left, and lateral view, right.

compressed) anterior process; and compound posterior process with a marked facial nerve sulcus, similar to the narrower and more elongated process of balaenopterids (Ekdale et al., 2011). Notable primitive characters of the periotic include: a superior process; and an internal acoustic meatus with a single large aperture without a prominenttransverse crest (Hernández-Cisneros et al., 2014). The fossils are too incomplete to assess possible synapomorphies for Chaeomysticeti, such as absence of teeth (Mitchell, 1989) or an orbital crest well positioned anteriorly on the dorsal surface of the frontal (Geisler and Sanders, 2003). But, other features indicate that the fossils are a species of chaeomysticetes: compound posterior process of the periotic; transversally widened intertemporal constriction; triangular shape of the supraoccipital, and a postglenoid process of the squamosal posteriorly directed in lateral view (see Marx and Fordyce, 2015, on these features). The specimens MU EcSj5/06/31 and MU EcSj5/18/95 are quite different from Horopeta umarere Tsai and Fordyce, 2015, Whakakai waipata Tsai and Fordyce, 2016, and M. parki Benham, 1937 (see also Fordyce, 2005) mainly in the ear bone morphology and other cranial features (Hernández-Cisneros unpublished data).

\subsubsection{SUBORDER ODONTOCETI-ARCHAIC ODONTOCETES}

Odontoceti Flower, 1867

Family indet. gen. et. sp. indet.

Material. MHN-UABCS_EcSj5/12/48, skull, right forelimb (humerus, radio, ulna), periotics, right bulla, cervical vertebrae, and teeth (Figure $5 \mathrm{~A})$. 
Locality. San Juan de la Costa, El Saladito, mine spoils (24.44249 N, 110.69106 W), La Paz, Baja California Sur, México. Collected by Miguel Angel Meza Ortega; Shelton P. Applegate, Gerardo González Barba, Andreas Knieth and Lawrence G. Barnes February 1993.

Formation. El Cien Formation.

Age. 28 to $25 \mathrm{Ma}$ approximately, Late Oligocene (Fischer et al., 1995).

Description. The specimen (Figure 5A) consists of a partial skull with a preserved length of $\sim 400$ mm (substantially less than condylobasal lengthbecause of loss of the rostrum apex), bizygomatic width estimated at $\sim 200 \mathrm{~mm}$, and estimated body size of $\sim 1.41 \mathrm{~m}$ (following the equation for stem Odontoceti in Pyenson and Sponberg, $2011)$. The inferred age class is adult, as indicated by completely closed cranial sutures, a developed nuchal crest, and epiphyses fused to the cervical vertebra body (on significance of fusion, see Perrin, 1975). MU EcSj5/12/48 was earlier referred to as "Agorophius" sp. (Cruz-Marín, 1997), but its morphology is quite different to Agorophiidae (Fordyce, 1981, Godfrey et al., 2016) and closer to Simocetus rayi Fordyce, 2002. Amongst features of note, the specimen is small compared with both $S$. rayi (condylobasal length: $449+\mathrm{mm}$; bizygomatic width: $238 \mathrm{~mm}$, Fordyce, 2002) and Agorophius pygmaeus (Müller, 1849) (condylobasal length: 450-500 mm; bizygomatic width: $\sim 200+\mathrm{mm}$ ). The skull has a shortened rostrum with a narrow snout and short mesorostral groove, and a supraoccipital shield with a semicircular outline behind the anterior margin of the squamosal fossa. The intertemporal region is prominent. The small teeth are heterodont but not polydont. The maxilla rises posteriorly over the frontal, extended near to the frontoparietal suture; laterally overlaps part of the supraorbital process, but does not reach the supraorbital margin, leaving the rest of the frontal exposed dorsally above the elevated roof of the orbit. The premaxillary sac fossa and associated foramina and sulci lie well forward on the rostrum, anterior to the antorbital notch. Many of the latter
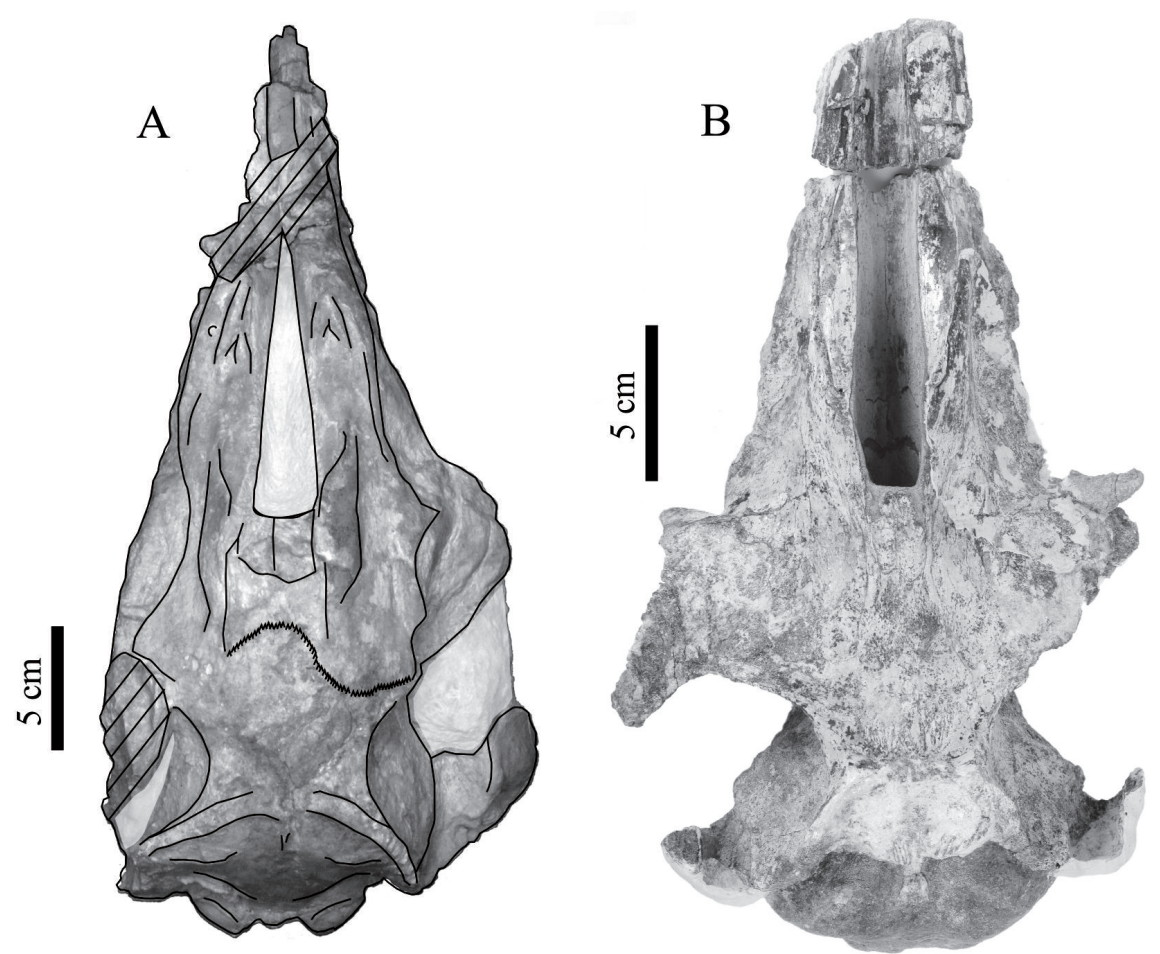

Figure 5 (A) Dorsal view, skull of unnamed archaic odontocete, MU EcSj5/12/48. (B) Dorsal view, skull of an unnamed archaic odontocete, MU EcSj24/50/183 (Fordyce et al., 2012). Continuous lines show anatomical details and diagonal lines mark broken areas. Shaded white areas show sediment matrix. 
are plesiomorphic features shared with $S$. rayi and A. pygmaeus, and for now they do not help with taxonomy. Systematic questions should be resolved by a detailed morphological description and phylogenetic analysis.

Family indet. gen. et. sp. indet.

Material. MNH-UABCS_EcSj24/50/183, skull (Figure 5B).

Locality. San Juan de la Costa, Arroyo Tarabillas, mine spoils $\left(24.44249^{\circ} \mathrm{N}, 110.69106^{\circ} \mathrm{W}\right) \mathrm{La}$ Paz, Baja California Sur, México. Collected by Robert Ewan Fordyce; Gerardo González Barba; Priscila Morales Ortega; Ricardo Mirsha Martín Mata Cruz, and Atzcalli Ehécatl Hernández Cisneros. February 2008.

Formation. El Cien Formation.

Age. 28 to $25 \mathrm{Ma}$ approximately, Late Oligocene (Fischer et al., 1995).

Description. The specimen (Figure 5B) consists of a partial skull with a preserved length of $\sim 305 \mathrm{~mm}$ but judging from comparable specimens (USNM 205491, below) its condylobasal length could have been double the preserved length. The inferred age class is adult, as indicated by cranial sutures which are relatively closed and tight. Features of note include the prominent narial "snout", and archaic features like parietals exposed at a prominent intertemporal constriction, plus premaxilla without a posterolateral fold but with a narrow and elongate premaxillary sac fossa (Fordyce et al., 2012). The skull is more dorsoventrally flat than $S$. rayi Fordyce (2002), Albertocetus meffordorum Uhen (2010), Waipatiidae (Fordyce, 1994; Tanaka and Fordyce, 2014, 2015a, 2015b), Patriocetus ehrlichi (Van Beneden, 1865), Patriocetus kazakhstanicus, Dubrovo and Sanders, 2000, or the unnamed specimen USNM 205491 from Oregon (Fordyce et al., 2012). The rostrum is less concave and, the premaxillary sac fossae are more anterior and shallow than S. rayi. Other features include: the narrow and relatively long nasals, an elongate and narrow postorbital process of the frontal; and the flat, wide and slightly concave palatine.
Fordyce et al. (2012) identified the specimen as a possible Dalpiazinidae, but the typology of that family is now considered uncertain, and the specimen is not allocated to the family.

\subsubsection{SUBORDER 'ARCHAEOCETI' ?KEKENODONTIDAE}

Archaeoceti Flower, 1883

?Kekenodontidae Mitchell, 1989

?Kekenodontidae gen. et. sp. indet.

Material. MHN-UABCS_EcSj5/16/267, left periotic (Figure 6A).

Locality. San Juan de la Costa, El Saladito, mine spoils (24.44249 N, $110.69106^{\circ} \mathrm{W}$ ), La Paz, Baja California Sur, México. Collected by Gerardo González Barba; Lawrence G. Barnes, and Arturo Gruz Marin. March 1993.

Formation. El Cien Formation.

Age. $\sim 27 \mathrm{Ma}$ approximately, Late Oligocene (Fischer et al., 1995).

Description. The specimen (Figure 6A) is a left periotic without the posterior process, and with a shape similar to that of basilosaurids (Kellogg, 1936; Luo and Gingerich, 1999; Uhen, 2004; Fitzgerald, 2010), and contrast widely with the morphology present in mysticetes and odontocetes (Hernández-Cisneros and Tsai, 2016). The periotic has a maximum preserved length of 51 $\mathrm{mm}$. Features of note include the elongate body which is transversely narrow in ventral view, like Kekenodon onamata Hector, 1881 (see Hector's Fig. 10), and is quite similar to the undescribed specimen OU 22294 (Fordyce 2004; Clementz et al., 2014) from New Zealand. The suprameatal area is ovoid; the superior process is low compared with the high structure seen in Zygorhiza kochii (Reichenbach, 1847), Dorudon atrox (Andrews, 1906), or Basilosaurus isis (Andrews, 1904). In lateral view the shape is rectangular, the superior process has a concave profile and the anterior process is trapezoidal-rectangular in medial view. The periotic, MU EcSj5/16/267, is similar to the elements of the unprepared specimen, MU EcSj1/45/214, but it is not clear whether these are the same 

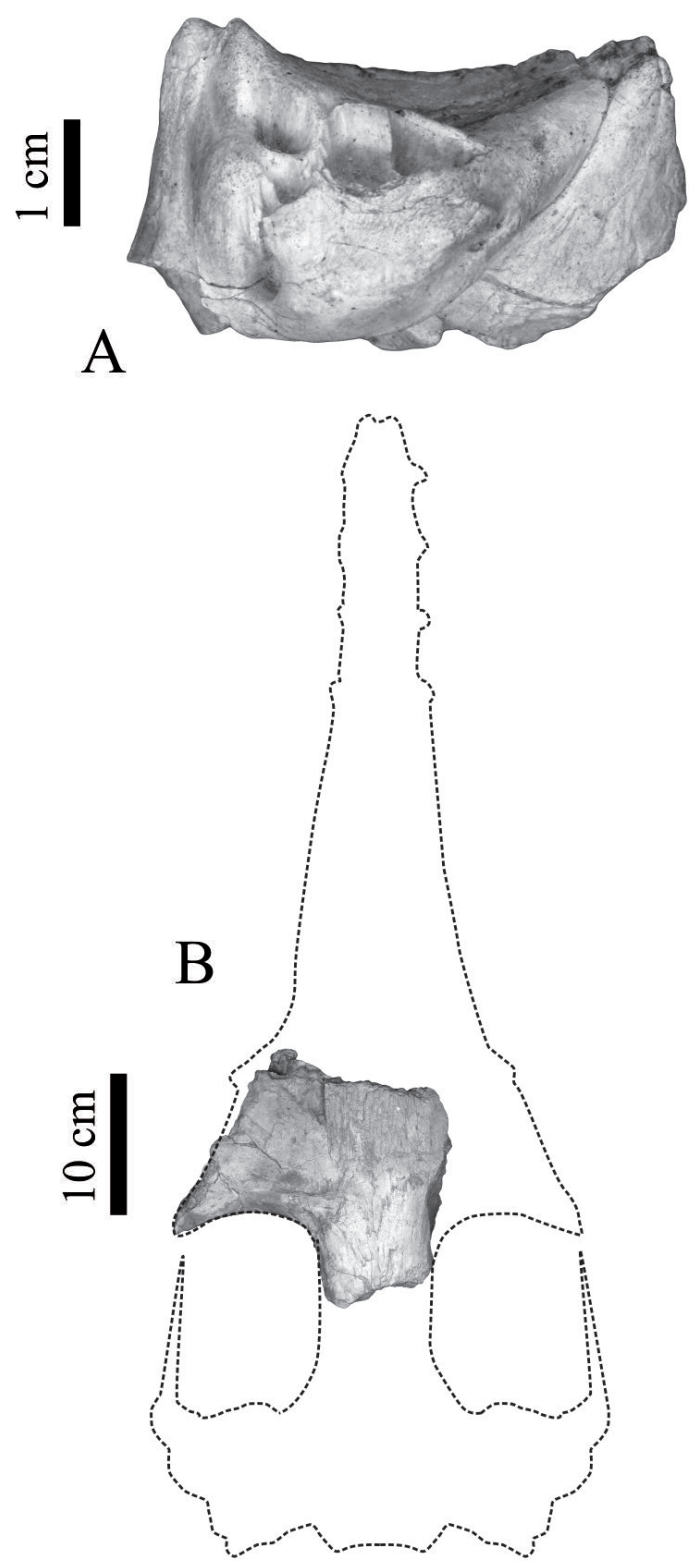

Figure 6 (A) Medial view, left periotic, ?kekenodontid-like animal, MU EcSj5/16/267. (B) Dorsal view of a frontal fragment, ?kekenodontid-like animal, specimen MU EcSj5/16/72, dashed lines mark missing anatomy.

species; detailed description and comparison are needed. Other unprepared specimens, such as MU EcSj5/16/72 (partial frontal, Figure 6B); MU EcSj1/94/296 and MU EcSj1/38/155 (partial skulls), are phenetically similar to the undescribed specimen OU 22294 (Clementz et al.,
2014: Fig. 2) in a narrow and longest intertemporal region, short zygomatic process, and a flat braincase (Hernández-Cisneros, 2015).

\section{Discussion}

Cetaceans from Baja California Sur contribute towards the continually expanding Late Oligocene history of Cetacea around the Pacific Basin. Barnes (1998) briefly discussed apparent differences of the Oligocene cetaceans from Mexico with other areas of the Pacific margin, remarking upon similarity with the fossil cetacean assemblage from the Olympic Peninsula in Washington (U.S.A.) and differences with Oligocene cetaceans from Hokkaido (Japan), and New Zealand. Given the rapidly expanding diversity of Oligocene Cetacea from Baja California Sur and New Zealand, comparisons may become outdated unless species are formally described.

At present, the reported Oligocene cetaceans from the Pacific Basin include several formally named species (Appendix, Table A1). Many recent advances in cetacean paleontology have expanded the framework of Oligocene cetacean evolution and its diversity, e.g. Fitzgerald (2010); Boessenecker and Fordyce (2014, 2015a, 2015b); Tsai and Fordyce (2015); Tanaka and Fordyce (2014, 2015a, 2015b), and others. The nature of the specimens means that many of the latter articles are detailed morphological accounts with cladistic analyses of large character matrices. In spite of such advances, there is a much greater known diversity -as revealed by undescribed museum collectionsthan is apparent from the literature. Thus, there is a considerable information gap about the Oligocene cetaceans (Uhen and Pyenson, 2007), which include a critical link between archaeocetes and the Neogene cetacean groups (Fordyce et al., 1995). The Late Oligocene cetacean fossils from Baja California Sur will elucidate evolution of the Cetacea including morphological transitions, functional and ecological shifts, and changing biogeography. 


\section{Conclusion}

Baja California Sur has produced some important Cenozoic fossils assemblages distributed along the Peninsula, including Late Oligocene marine mammals (mostly cetaceans and a few desmostylians) reported briefly in the last 70 years. Published details are sparse, and some appear only in theses or abstracts. These fossils represent the southern-most records of Late Oligocene cetaceans from North America. There is a great expectation to increase the knowledge of cetacean diversity as fieldwork continues and the specimens collected in museums are prepared. Recent studies indicate the presence of hitherto unreported archaic odontocetes, mysticetes (Aetiocetidae and Chaeomysticeti), and kekenodontid-like cetaceans, mostly from the El Cien Formation (Oligocene-Early Miocene) and San Gregorio Formation (Late Oligocene). As with new fossil cetaceans from elsewhere in the world, the materials will expand understanding of diverse aspects of cetacean evolution.

\section{Acknowledgments}

We give our thanks to the editors, to Sergio Lucero and anonymous reviewer for their assistance and comments. We also thank Cheng-Hsiu Tsai and Robert W. Boessenecker for their comments and constructive criticism during the preparation of this work, to the collectors especially to Lawrence G. Barnes and James Goedert, to Maria Guadalupe González for their support with the stratigraphic columns. Thanks to J. Lopez-Calderon for the comments and review. Thanks to Tobias Schwennicke for its comments about geology details, and to Enrique H. Nava Sánchez for supporting field work and for comments (project SIP: 20131259). We thank CONACYT (Beca Mixta, 290842), CICIMAR-IPN (SAI), CGA-IPN and COSCyT-BCS for financial support for the internship in New Zealand, that made this work possible. This study was developed during AEHC's
MSc thesis supported by Instituto Politécnico Nacional - Centro Interdisciplinario de Ciencias Marinas (CICIMAR-IPN), and the Consejo Nacional de Ciencia y Tecnología (CONACYT) scholarship, 290143.

\section{References}

Alexadri-Rionda, R., Martínez-Vera, A., EspinosaAramburu, E.G., Terán-Ortega, L.A., Maraver-Romero, D.V., Arriaga-Meléndez, H., 2008, Carta Geológico-Minera Estado de Baja California Sur, 1: 500000: Distrito Federal, México, Servicio Geológico Mexicano, Secretaria de Economía, 1 mapa.

Andrews, C. W., 1904, Further notes on the mammals of the Eocene of Egypt. Part III: Geological Magazine, 5, 11-215.

Andrews, C. W., 1906, A Descriptive Catalogue of the Tertiary Vertebrata of Fayum, Egypt: London, British Museum, 1-324.

Applegate, S.P., 1986, The El Cien Formation, strata of Oligocene and Early Miocene age in Baja California Sur: Revista Mexicana de Ciencias Geológicas, 6, 145-162.

Applegate, S.P., Wilson, E.C., 1976, Correlation of fossiliferous Upper Oligocene or Lower Miocene sections at San Telmo Point and Arroyo Guadalupe, Baja California Sur, México, and a possible new phosphate source (resumen), in III Congreso Latinoamericano de Geología: México, Instituto de GeologíaUniversidad Nacional Autónoma de México, 6.

Barnes, L.G., 1998, The sequence of fossil marine mammal assemblages in México, Avances en investigación: Paleontología de Vertebrados, 1, 26-79.

Barnes, L.G., Kimura, M., Furusawa, H., Sawamura, H., 1995, Classification and distribution of Oligocene Aetiocetidae (Mammalia; Cetacea; Mysticeti) from western North America and Japan: The Island Arc, 3, 392-431. 
Benham, W.B., 1937, On Lophocephalus, a new genus of zeuglodont Cetacea: Transactions and Proceedings of the Royal Society of New Zealand, 67, 1-7.

Boessenecker, R.W., Fordyce, R.E., 2014, A new eomysticetid (Mammalia: Cetacea) from the Late Oligocene of New Zealand and a reevaluation of "Mauicetus" waitakiensis: Papers in Palaeontology, 1-34, doi: 10.1002/ spp2.1005.

Boessenecker, R.W., Fordyce R.E., 2015a, Anatomy, feeding ecology, and ontogeny of a transitional baleen whale: a new genus and species of Eomysticetidae (Mammalia: Cetacea) from the Oligocene of New Zealand: PeerJ, 3, e1129, 1-69.

Boessenecker, R.W., Fordyce, R.E., 2015b, A new genus and species of eomysticetid (Cetacea: Mysticeti) and a reinterpretation of "Mauicetus" lophocephalus Marples, 1956: Transitional baleen whales from the upper Oligocene of New Zealand: Zoological Journal of the Linnean Society, 175, 607-660.

Boessenecker, R.W., Fordyce, R.E., 2016, A new eomysticetid from the Oligocene Kokoamu Greensand of New Zealand and a review of the Eomysticetidae (Mammalia, Cetacea): Journal of Systematic Palaeontology, 1-41, doi: 10.1080/14772019.2016.1191045.

Brisson, M. J., 1762, Regnum Animale in classes IX distributum, sive synopsis methodica: Netherlands, Lugduni Batavorum, 296 p.

Bukry, D., 1978, Cenozoic silicoflagellate and Coccolith stratigraphy, northwestern Atlantic Ocean, DSDP Leg 43, in Benson, W.E., Sheridan, R.E., Pastouret, L., Enos, P., Freeman, T., Murdmaa, I.O., Worstell, P, Gradstein, F., Schmidt, R.R., Weaver, F.M., Stuermer, D.H. (eds.), Init. Repts. DSDP, 44: Washington, U.S.A. Govt. Printing Office, 775-805, doi:10.2973/dsdp.proc.44.1978.

Clementz, M.T., Fordyce, R.E., Peek, S.L., Fox, D.L., 2014, Ancient marine isoscapes and isotopic evidence of bulk-feeding by Oligocene cetaceans: Palaeogeography,
Palaeoclimatology, Palaeoecology, 400, 28-40.

Cornwall, I.A., 1922, Some notes on the Sooke Formation, Vancouver Island, B.C.: Canadian Field Naturalist, 36, 121-123.

Cruz-Marín, A., 1997, Un fósil de odontoceto del miembro San Juan (Oligoceno Superior) de la Formación El Cien de San Juan de la Costa, Baja California Sur, México: Baja California Sur, México, Centro Interdisciplinario de Ciencias Marinas-Instituto Politécnico Nacional, tesis de maestría, 58 p.

Deméré, A.T., Berta, A., 2008, Skull anatomy of the Oligocene toothed mysticete Aetiocetus weltoni (Mammalia; Cetacea): implications for mysticete evolution and functional anatomy: Zoological Journal of the Linnean Society, 154, 308-352.

Downs, T., Morris, W.J., 1974, A paleontologic reconnaissance in Baja California, in Oehser PH, Lea, JS, Powars, NL (eds.), Progress report, National Geographic Society (1971, 1973, 1974): Washington, D.C., National Geographic Society, 15, 157-174.

Dubrovo, I.A., Sanders, A.E., 2000, A new species of Patriocetus (Mammalia, Cetacea) from the Late Oligocene of Kazakhstan: Journal of Vertebrate Paleontology, 20, 577-590.

Durham, J.W., 1950, Megascopic paleontology and marine stratigraphy. Part 2 of the "E.W. Scripps" cruise to the Gulf of California: Memoirs of the Geological Society of America, 43, 1-213.

Ekdale, E.G., Berta, A., Deméré, T.A., 2011, The comparative osteology of the petrotympanic complex (ear region) of extant baleen whales (Cetacea: Mysticeti): PloS ONE, 6, 1-42.

Emlong, D., 1966, A new archaic cetacean from the Oligocene of Northwest Oregon: Bulletin of the Museum of Natural History, 3, 1-51.

Fenner, J., 1982, Diatoms in the Eocene and Oligocene Sediments off N. W. Africa, Their Stratigraphic and Paleogeographic Occurrences: Kiel, Germany, University of Kiel, Ph.D. dissertation, 230 p. 
Fischer, R., Galli-Oliver, C., Gidde, A., Schwennicke, T., 1995, The El Cien Formation of southern Baja California, México: Stratigraphic precisions: Newsletters on Stratigraphy, 32, 137-161.

Fitzgerald, E.M.G., 2006, A bizarre new toothed mysticete (Cetacea) from Australia and the early evolution of baleen whales: Proceedings of the Royal Society B: Biological Sciences, 273, 2955-2963.

Fitzgerald, E.M.G., 2010, The morphology and systematics of Mammalodon colliveri (Cetacea: Mysticeti), a toothed mysticete from the Oligocene of Australia: Zoological Journal of the Linnean Society, 158, 367-476.

Flower, W. H., 1883, On the arrangement of the Orders and Families of existing Mammalia: Proceedings of the Zoological Society of London, 13, 178-186

Flower, W. H., 1867, Description of the skeleton of Inia geoffrensis and the skull of Pontoporia blainvillii: Transactions of the Zoological Society of London, 6, 87-116.

Fordyce, R.E., 1981, Systematics of the odontocete whale Agorophius pygmaeus and the Family Agorophiidae (Mammalia: Cetacea): Journal of Paleontology, 55, 1028-1045.

Fordyce, R.E., 1994, Waipatia maerewhenua, new genus and new species (Waipatiidae, new family), an archaic Late Oligocene dolphin (Cetacea: Odontoceti: Platanistoidea) from New Zealand: Proceedings of the San Diego Society of Natural History, 29, 147-176.

Fordyce, R.E., 2002, Simocetus rayi (Odontoceti: Simocetidae, New Family): A bizarre New archaic Oligocene dolphin from the Eastern North Pacific: Smithsonian contributions to Paleobiology, 93, 185-221.

Fordyce, R.E., 2004, The transition from Archaeoceti to Neoceti: Oligocene archaeocetes in the Southwest Pacific: Journal of Vertebrate Paleontology, 24(3, supplement), 59A.
Fordyce, R.E., 2005, New specimen of archaic baleen whale Mauicetus parki (Late Oligocene, New Zealand) elucidates early crownmysticeti: Journal of Vertebrate Paleontology, 25(3, supplement), 58A.

Fordyce, R.E., Barnes, L.G., Miyazaki, N., 1995, General aspects of the evolutionary history of whales and dolphins: The island Arc, 3, 373-391.

Fordyce, R.E., de Muizon, C., 2001, Evolutionary history of cetaceans: a review, in Mazin, J.M., de Buffrénil V. (eds.), Secondary adaptation of tetrapods to life in water: München, Germany, Verlag Dr. Friedrich Pfeil, 169-233.

Fordyce, R.E., Marx, F.G., 2016, Mysticetes baring their teeth: a new fossil whale, Mammalodon hakataramea, from the Southwest Pacific: Memoirs of Museum Victoria, 74, 107-116.

Fordyce, R.E., Fitzgerald, E.M.G., GonzálezBarba, G., Aguirre-Fernandez, G., 2012, Long-tusked archaic Oligocene odontocetes from Oregon and Baja California Sur, eastern Pacific margin Journal of Vertebrate Paleontology, 32(3, supplement), 95A.

Galli-Olivier, C., 1993, Fosforita de San Juan de la Costa (Bahía de La Paz), Baja California Sur, México: 17 años de investigaciones: Revista de Investigación Científica, 4, 115-135.

Galli-Olivier, G., Garduño, G., Gamiño, J., 1990, Phosphorite deposits in the Upper Oligocene, San Gregorio Formation at San Juan de la Costa, Baja California Sur; México, in Burnett, W.C., Riggs, S.R. (eds.), Phosphate deposits of the world 3. Neogene to modern phosphorites: Cambridge, UK, Cambridge University press, $122-126$.

Ganz, B., 1996, Geologische Kartierung der nördlichen Umgebung von $\mathrm{La}$ Purísima (Baja California Sur, Mexiko), fazielle Untersuchung der San GregorioFormation und Vergleich mit der San JuanEinheit: Germany, Universität Hannover, undergraduate dissertation, $96 \mathrm{p}$. 
Geisler, J.H., Sanders, A.E., 2003, Morphological evidence for the phylogeny of Cetacea: Journal of Mammalian Evolution, 10(1/2), 23-129.

Godfrey, S.J., Uhen, M.D., Osborne, E.J., Edwards, L.E., 2016, A new specimen of Agorophius pygmaeus (Agorophiidae, Odontoceti, Cetacea) from the early Oligocene Ashley Formation of South Carolina, USA: Journal of Paleontology, 90, 154-169.

González-Barba, G. 2007, The Late Oligocene marine mammal assemblage of the San Juan and Tembabichi Members (El Cien Formation), Baja California Sur, México, in Warren, A. (eds), Conference on Australasian Vertebrate Evolution: Paleontology and Systematics: Australia, Geological Society of Australia, 85.

González-Barba, G., 2008, Descripción de la asociación faunística de elasmobranquios fósiles del conglomerado basal en las Formaciones San Gregorio y El Cien (Oligoceno Temprano) de Baja California Sur, México: Baja California Sur, México, Centro Interdisciplinario de Ciencias Marinas - Instituto Politécnico Nacional, tesis doctoral, $226 \mathrm{p}$.

Gray, J. E., 1864, On the cetaceous mammals, in Richardson, J., Gray, J. E. (eds), The zoology of the voyage of the H.M.S. Erebus and Terror, under the command of Capt. Sir. JC Ross, RN, FRS, during the years 1839-1843, Vol. 1 \& 2: London, UK, E.W. Janson, 1-53. Grimm, K.A., 1992, The sedimentology of coastal upwelling systems: California, U.S.A., University of California, $\mathrm{PhD}$ thesis, $431 \mathrm{p}$.

Grimm, K.A., Föllmi, K.B., 1994, Doomed pioneers: allochthonous crustacean tracemakers in anaerobic basinal strata, Oligo-Miocene San Gregorio Formation, Baja California Sur, Mexico: Palaios, 9, 313-334.
Hausback, B.P., 1984, Cenozoic volcanic and tectonic evolution of Baja California Sur, Mexico, in Frizzell, V.A. (ed.), Geology of the Baja California Peninsula: California, U.S.A., Pacific Section S.E.P.M., 39, 219-236.

Hector, J., 1881, Notes on New Zealand Cetacea, recent and fossil: Transactions and Proceedings of the Royal Society of New Zealand, 13, 434-436.

Hernández-Cisneros, A.E., 2012, Registro fósil de cetáceos del Oligoceno en las formaciones San Gregorio y El Cien, Baja California Sur, México: Baja California Sur, México, Universidad Autónoma de Baja California Sur, undergraduate dissertation, $42 \mathrm{p}$.

Hernández-Cisneros, A.E., 2014, Chaeomysticeti, ballenas barbadas del Oligoceno Tardío en Baja California Sur: Baja California Sur, México, Centro Interdisciplinario de Ciencias Marinas - Instituto Politécnico Nacional, master thesis, $101 \mathrm{p}$.

Hernández-Cisneros, A.E., 2015, Un enigmático grupo de cetáceos dentados afín a la familia Kekenodontidae, Oligoceno Tardío, México (abstract), in Reynoso, V.H., Flores-Mejía, P., Moreno-Bedmar, J.A. (eds), Programa de resúmenes del XIV Congreso Mexicano de Paleontología: Melchor Múzquiz: Distrito Federal, México, Sociedad Mexicana de Paleontología, A. C. - Paleontología Mexicana, Volumen especial 1, 40-41.

Hernández-Cisneros, A.E., González-Barba, G., 2013, Registro fósil de cetáceos del Oligoceno en Baja California Sur, México, in ReynosoRosales, V.H., Oseguera-Montiel, B., FloresMejía, P. (eds.), Programa y Resúmenes del VIII Congreso Latinoamericano de Paleontología \& XIII Congreso Mexicano de Paleontología: Guanajuato, México, Sociedad Mexicana de Paleontología, A.C., Museo Dugès, Universidad de Guanajuato, 56. 
Hernández-Cisneros, A.E., Nava-Sánchez, E.H., González-Barba, G., 2014, Late Oligocene mysticetes (Chaeomysticeti) from Baja California Sur, Mexico, in Cerdeño, E. (ed), Abstract Volume, $4^{\text {th }}$ International Palaeontological Congress: Mendoza, Argentina, International Palaeontological Association, 535.

Hernández-Cisneros, A.E., Tsai C-H., 2016, A possible enigmatic kekenodontid (Cetacea, Kekenodontidae) from the Oligocene of Mexico: Paleontología Mexicana, 5(2), 147-155.

Jousé, A.P., 1973, Diatoms in the OligoceneMiocene biostratigraphic zones of the tropical areas of the Pacific Ocean: Beihefte zur Nova Hedwigia, 45, 333-357.

Kellogg, A.R., 1936, A review of the Archaeoceti: Washington, Carnegie Institution of Washington, 482, 455 p.

Kim, W.H., 1987, Biostratigraphy and depositional history of the San Gregorio and Isidro Formations, Baja California Sur, Mexico: California, U.S.A., Stanford University, doctoral thesis, $206 \mathrm{p}$.

Kim, W.H., Barron, J.A., 1986, Diatom biostratigraphy of the upper Oligocene to lowermost Miocene San Gregorio Formation, Baja California Sur: Diatom Research, 1, 169-187.

Luo, Z., Gingerich, P.D., 1999, Terrestrial Mesonychia to aquatic Cetacea: transformation of the basicranium and evolution of hearing in whales: University of Michigan, Papers on Paleontology, 31, 110 p.

Marples, B.J., 1956, Cetotheres (Cetacea) from the Oligocene of New Zealand: Proceedings of the Zoological Society of London, 126, 565-580.

Marx, F.G., Fordyce, R.E., 2015, Baleen boom and bust: a synthesis of mysticete phylogeny, diversity and disparity: Royal Society Open Science, 2(140434), 14.
Marx, F.G., Tsai, C-H., Fordyce, R.E., 2015, A new Early Oligocene toothed "baleen" whale (Mysticeti: Aetiocetidae) from western North America: one of the oldest and the smallest: Royal Society Open Science, 2(150476), 35 p.

McLean, H., Hausback, B.P., Knapp, J.H., 1987, The Geology of West-Central Baja California Sur, México: U.S Geological Survey Bulletin, 1579, $16 \mathrm{p}$.

Mitchell, E.D., 1989, A new cetacean from the Late Eocene La Meseta Formation, Seymour Island, Antarctic Peninsula: Canadian Journal of Fisheries and Aquatic Science, 46, 2219-2235.

Müller, J., 1849, Über die fossilen Reste der Zeuglodonten von Nordamerica: Berlin, Verlag von G. Reimer, 1-38.

Okazaki, Y., 1995, A new type of primitive baleen whale (Cetacea; Mysticeti) from Kyushu Japan: The Island Arc, 3, 432-435.

Okazaki, Y., 2012, A new mysticete from the upper Oligocene Ashiya Group, Kyushu, Japan and its significance to mysticete evolution: Bulletin of the Kitakyushu Museum of Natural History and Human History Series A, 10, 129-152.

Olivares-Bañuelos, N.C., 2001, Descripción y análisis taxonómico de un misticeto dentado fósil del Miembro San Juan, Formación El Cien, Baja California Sur, México: Baja California Sur, México, Universidad Autónoma de Baja California sur, tesis de licenciatura, $75 \mathrm{p}$.

Perrin, W.F., 1975, Variation of spotted and spinner porpoise (genus Stenella) in the Eastern Pacific and Hawaii: Bulletin of the Scripps Institution of Oceanography, 21, 1-206.

Plata-Hernández, E., 2002, Cartografía y estratigrafía del área de Tembabichi, Baja California Sur, México: Baja California Sur, México, Universidad Autónoma de Baja California Sur, undergraduate dissertation, $147 \mathrm{p}$. 
Plata-Hernández, E., Schwennicke, T., 2000, Estratigrafia de la región de Tembabichi, Baja California Sur, México (extended abstract), in XVII Simposio sobre la Geología de Latinoamérica, 18, 6 p.

Pledge, N.S., 2005, A new species of early Oligocene cetacean from Port Willunga, South Australia: Memoirs of the Queensland Museum, 51, 123-133.

Pyenson, N.D., Sponberg, S.N., 2011, Reconstructing body size in extinct crown Cetacea (Neoceti) using allometry, phylogenetic methods and tests from the fossil record: Journal of Mammal Evolution, 18, 269-288.

Reichenbach, L., 1847, Systematisches, in Carus, C. G., Resultate geologischer, anatomischer und zoologischer untersuchungen über das unter den Namen Hydrarchos von D .

A. C. Koch zuerst nach Europa gebrachte und in Dresden augestelte grofse fossile Skelett: Dresden, Germany, Arnoldische Buchhandlung, $15 \mathrm{p}$.

Russell, L.S. 1968, A new cetacean from the Oligocene Sooke Formation of Vancouver Island, British Columbia: Canadian Journal of Earth Science, 5, 929-933.

Sanders, A.E., Barnes, L.G., 2002a, Paleontology of the Late Oligocene Ashley and Chandler Bridge Formations of South Carolina, 2: Micromysticetus rothauseni, a primitive cetotheriid mysticete (Mammalia: Cetacea): Smithsonian contributions to Paleobiology, 93, 271-293.

Sanders, A.E., Barnes, L.G., 2002b, Paleontology of the Late Oligocene Ashley and Chandler Bridge Formations of South Carolina, 3: Eomysticetidae, a new family of primitive mysticetes (Mammalia: Cetacea): Smithsonian contributions to Paleobiology, 93, 313-356.

Schweitzer, C.E., Feldmann, R.M., GonzálezBarba, G., Vega, FJ., 2002, New crabs from the Eocene and Oligocene of Baja California Sur, Mexico and an assessment of the evolutionary and paleobiogeographic implications of Mexican fossil decapods: Journal of Paleontology, 76, 1-43.

Schwennicke, T., 1992, Phosphoritführende Tief- und Flachwassersedimente aus dem Oberoligozän von Niederkalifornien, Mexiko - die San Juan-Einheit (El Cien-Formation): Hannover, Germany, Hannover University, doctoral thesis, $163 \mathrm{p}$.

Schwennicke, T., 1994, Deep and shallow water phosphorite-bearing strata of the Upper Oligocene of Baja California, Mexico (San Juan Member, El Cien Formation): Zentralblatt Geologie Paläontologie Teil I, 1, 567-580.

Schwennicke, T., Vásquez-García, A., 1996, Modelo deposicional de fosforita granular alóctona del Miembro San Juan (Oligoceno-superior) de la Formación El Cien en Baja California Sur y conclusiones paleogeográficas: Boletín del Departamento de Geología de la Universidad de Sonora, 13, 111-126.

Smith, J.T., 1991, Cenozoic marine mollusks and paleogeography of the Gulf of California, in Dauphin, J.P., Simoneit, R.T. (eds.), The Gulf and Peninsular province of the Californias: USA, American Association of Petroleum Geologists Memory, 47, 637-666.

Snavely, P.D., MacLeod, N.S., Rau W.W., Addicott W.O., Pearl E., 1975, Alsea Formation -an Oligocene marine sedimentary sequence in the Oregon coast range: U.S Geological Survey Bulletin, 1395, 21 p.

Tanaka, Y., Fordyce, R.E., 2014, Fossil dolphin Otekaikea marplesi (Latest Oligocene, New Zealand) expands the morphological and taxonomic diversity of Oligocene cetaceans: PLoS ONE, 9, $30 \mathrm{p}$.

Tanaka, Y., Fordyce, R.E., 2015a, Historically significant late Oligocene dolphin Microcetus hectori Benham 1935: a new species of Waipatia (Platanistoidea): Journal of the Royal Society of New Zealand, 45, 135-150. 
Tanaka, Y., Fordyce, R.E., 2015b, A new OligoMiocene dolphin from New Zealand: Otekaikea huata expands diversity of the early Platanistoidea: Palaeontologia Electronica, 18.2.23A, 1-71.

Tsai, G-H., Fordyce, R.E., 2015, The earliest gulpfeeding mysticete (Cetacea: Mysticeti) from the Oligocene of New Zealand: Journal of Mammalian Evolution, 22, 535-560,

Tsai, C.-H., Fordyce, R.E., 2016, Archaic baleen whale from the Kokoamu Greensand: earbones distinguish a new late Oligocene mysticete (Cetacea: Mysticeti) from New Zealand: Journal of the Royal Society of New Zealand, 1-22, doi: 10.1080/03036758.2016.1156552.

Tsai, C-H., Ando, T., 2015, Niche partitioning in Oligocene toothed mysticetes (Mysticeti: Aetiocetidae): Journal of Mammalian Evolution, 1-9, doi: 10.1007/ s10914-015-9292-y.

Uhen, M.D., 2004, Form, function, and anatomy of Dorudon atrox (Mammalia, Cetacea): an archaeocete from the Middle to Late Eocene of Egypt: University of Michigan, Papers on Paleontology, 34, 222 p.
Uhen, M.D., 2010, A new Xenorophus-like odontocete cetacean from the Oligocene of North Carolina and a discussion of the basal odontocete radiation: Journal of Systematic Palaeontology, 6, 433-452.

Uhen, M.D., Pyenson, N.D., 2007, Diversity estimates, biases, and historiographic effects: resolving cetacean diversity in the Tertiary: Palaeontologia Electronica, 10, 1-22.

Van Beneden, P.J., 1865, Recherches sur les ossements provenant du Crag d'Anvers Recherches sur les squalodons: Mémoires de l'Académie royale des sciences, des lettres et des beaux-arts de Belgique, 35, 1-85.

Vanderhoof, V.L., 1942, An occurrence of the Tertiary marine mammal Cornwallius in Lower California: American Journal of Science, 240, 298-301.

Vera-Dimas, D.R., 2013, Paleontología de macroinvertebrados marinos del Oligoceno (Miembros San Juan y Timbabichi, Formación El Cien) de Baja California Sur, México: Baja California Sur, México, Centro Interdisciplinario de Ciencias Marinas Instituto Politécnico Nacional, master thesis, $113 \mathrm{p}$ 


\section{APPENDIX}

Table A1. Recognized Oligocene cetaceans from the Pacific Basin.

\begin{tabular}{|c|c|c|c|}
\hline Taxon/species & Specimens & Country & References \\
\hline \multicolumn{4}{|l|}{ 'Archaeoceti' } \\
\hline Kekenodon onamata & NMNZ Ma. 306 & New Zealand & (Hector, 1881) \\
\hline Kekenodon sp. & OU22294 & New Zealand & (Fordyce, 2004; Clementz et al. , 2014) \\
\hline 'Squalodon' gambierensis & & Australia & (Fordyce, 2004; Fitzgerald, 2004) \\
\hline \multicolumn{4}{|l|}{ Mysticeti } \\
\hline Mammalodon colliveri & NMV P199986 & Australia & (Fitzgerald, 2010) \\
\hline Mammalodontidae gen. et sp. indet. & NMV P48794 & Australia & (Fitzgerald, 2010) \\
\hline Mammalodon hakataramea & OU 22026 & New Zealand & (Fordyce and Marx, 2016) \\
\hline Janjucetus hunderi & NMV P216929 & Australia & (Fitzgerald, 2006) \\
\hline Chonecetus sookensis & (NMC-VPC) 64443 & Canada & (Russell, 1968) \\
\hline Fucaia goedertorum & LACM 131146, LACM 138027 & USA & (Barnes et al., 1995) \\
\hline Fucaia buelli & UWBM 84024 & USA & (Marx et al., 2015) \\
\hline Ashorocetus eguchii & AMP No. 3 & Japan & (Barnes et al., 1995) \\
\hline Morawanocetus yabukii & AMP No. 1 & Japan & (Barnes et al., 1995) \\
\hline aff. Morawanocetus sp. & AMP No. 9 & Japan & (Tsai \& Ando, 2015) \\
\hline Aetiocetus tomitai & AMP No. 2 & Japan & (Barnes et al., 1995) \\
\hline Aetiocetus cotylalveus & USNM 25210 & USA & (Emlong, 1966) \\
\hline Aetiocetus weltoni & UCMP 122900 & USA & (Barnes et al., 1995) \\
\hline Aetiocetus polydentatus & AMP. No. 12 & Japan & (Barnes et al., 1995) \\
\hline Willungacetus aldingensis & SAMP40034 & Australia & (Pledge, 2005) \\
\hline Yamatocetus canaliculatus & KMNH VP 000,017 & Japan & (Okazaki, 1994, 2012) \\
\hline Tohoraata raekohao & OU 22178 & New Zealand & (Boessenecker \& Fordyce, 2014) \\
\hline Tohoraata waitakiensis & OMC GL 402 & New Zealand & (Boessenecker \& Fordyce, 2014) \\
\hline Tokarahia kauaeroa & OU 22235 & New Zealand & (Boessenecker \& Fordyce, 2015a) \\
\hline Tokarahia lophocephalus & OM GL 412 & New Zealand & (Boessenecker \& Fordyce, 2015a) \\
\hline Waharoa ruwhenua & OU 22044 & New Zealand & (Boessenecker \& Fordyce, 2015b) \\
\hline Matapanui waihao & OU 12918 & New Zealand & (Boessenecker \& Fordyce, 2016) \\
\hline Sitsqwayk cornishorum & UWBM 82916 & USA & (Peredo \& Uhen, 2016) \\
\hline 'Mauicetus' brevicollis & OM GL 410 & New Zealand & (Marples, 1956) \\
\hline Mauicetus parki & OU 11573, OU 22545 & New Zealand & (Benham, 1937, 1942; Fordyce, 2005) \\
\hline Horoperata umarere & OU21982 & New Zealand & (Tsai \& Fordyce, 2015b) \\
\hline Whakakai waipata & OU 21927 & New Zealand & (Tsai \& Fordyce 2016) \\
\hline \multicolumn{4}{|l|}{ Odontoceti } \\
\hline Waipatia maerewhenua & OU 22095 & New Zealand & (Fordyce, 1994) \\
\hline Otekaikea marplesi & OM GL 421 & New Zealand & (Tanaka \& Fordyce, 2014) \\
\hline Waipatia hectori & NMNZ MA 653 & New Zealand & (Tanaka \& Fordyce, 2015a) \\
\hline Otekaikea huata & OU 22306 & New Zealand & (Tanaka \& Fordyce, 2015b) \\
\hline Simocetus rayi & USNM 256517 & USA & (Fordyce, 2002) \\
\hline Arktocara yakataga & USNM 214830 & USA & (Boersma and Pyenson, 2016) \\
\hline
\end{tabular}




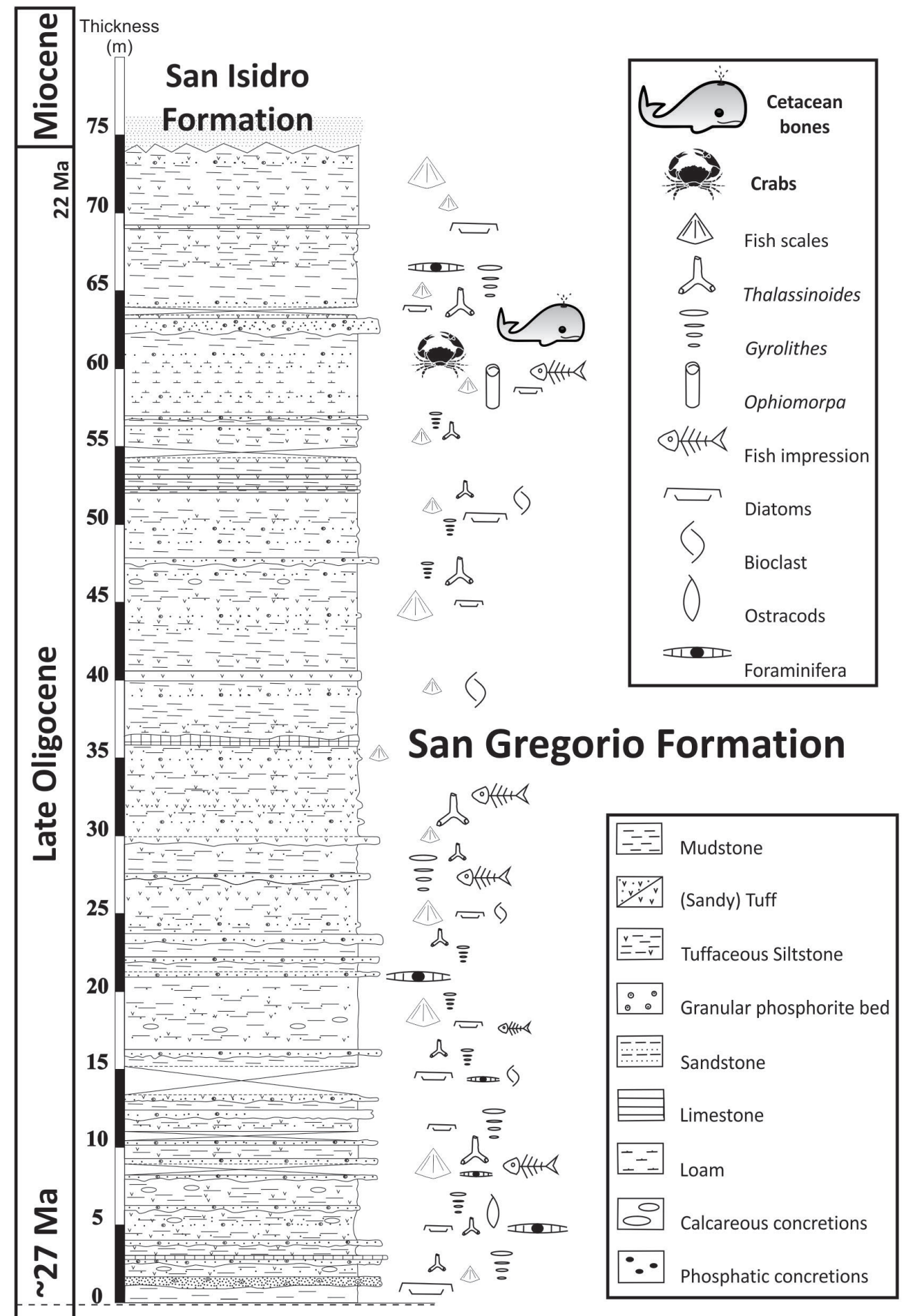

Not exposed

Figure A1 San Gregorio Formation, stratigraphic information summarized based on Ganz (1996), section from La Púrisima close to the Cerro El Pilón de San Isidro, Baja California Sur (26.198878 N, $\left.112.056659^{\circ} \mathrm{W}\right)$. Stratigraphic distributions of cetacean fossils and crabs are based on new observations (Hernández-Cisneros, 2012). The age is based on isotopic dates from the locality "Arroyo San Raymundo", 26.499422 N, 112.508537 W (McLean et al., 1987) and biostratigraphic data from "La Ventana" locality, 26.116680 N, 112.184059 W (Kim and Barron, 1986). 


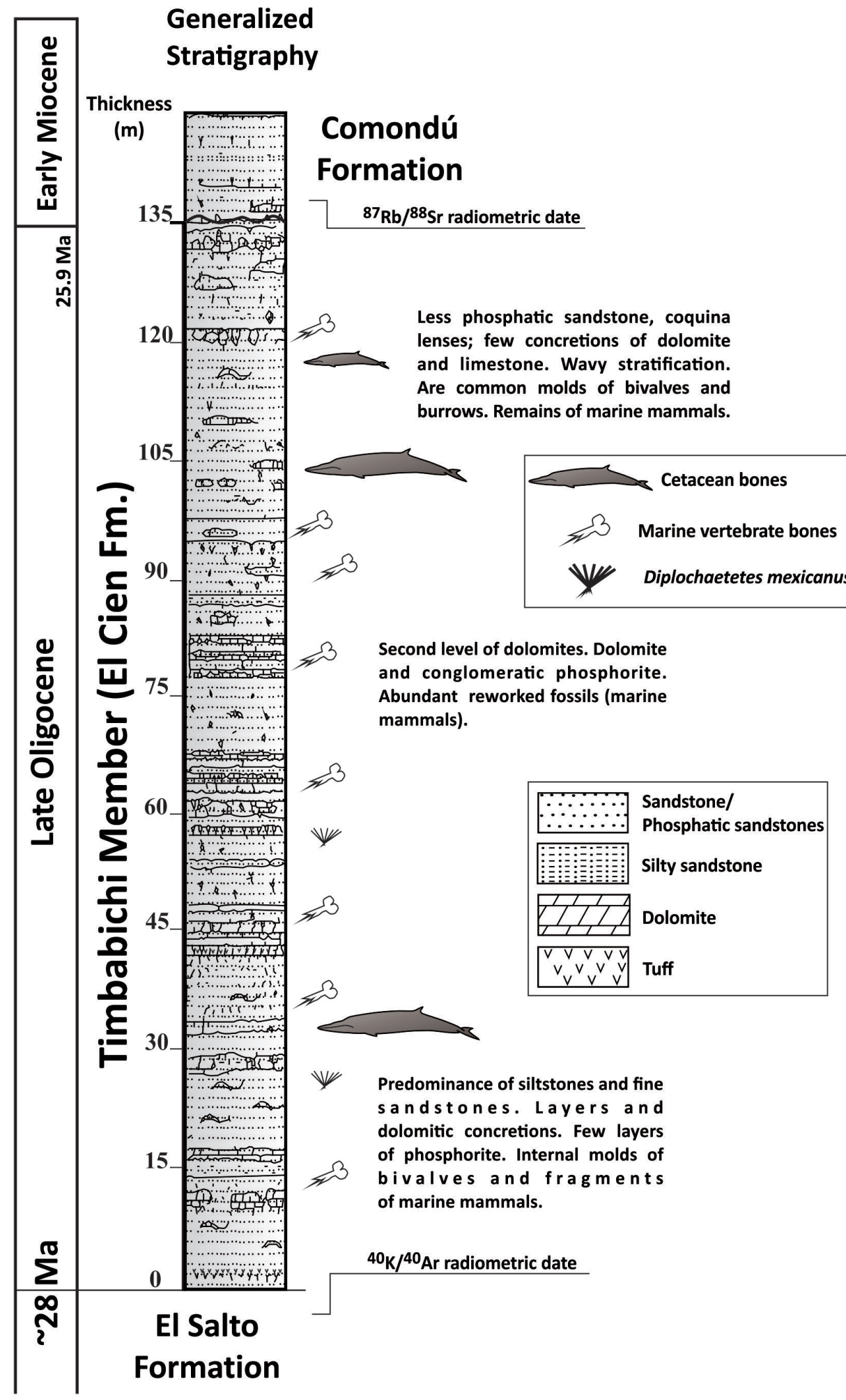

Figure A2 Generalized stratigraphy of Tembabichi Member, El Cien Formation (Plata-Hernandez, 2002), type section from cañada "La Calera" close to Tembabichi fisher village (25.26594167 N, 110.9622556 W). Stratigraphic distributions of cetacean fossils are based on new observations (Hernández-Cisneros, 2012). Tembabichi and San Juan members are considered correlative due lithological similarities (Plata-Hernandez, 2002) and share also some conspicuous invertebrate fossils as Diplochaetetes mexicanus, Anadara vanderhoofi, and Mytilus sp. (Fischer, et al., 1995, Vera-Dimas, 2013). 


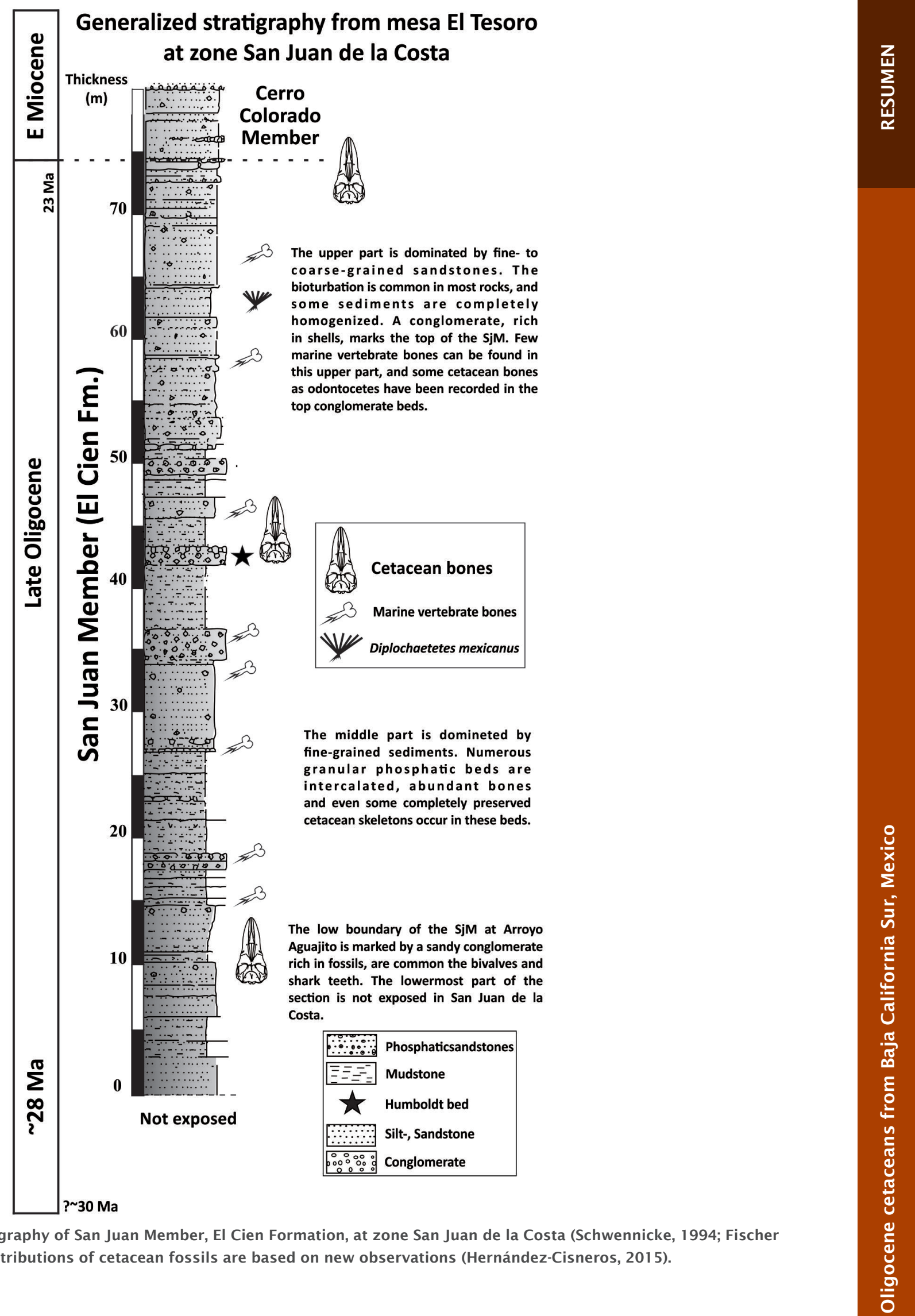

